Geological Magazine

Special Issue "Advances in Palaeogeography"

\title{
A historical account of how continental drift and plate tectonics provided the framework for our current understanding of palaeogeography
}

\author{
G. MEINHOLD*†‡ \& A. M. CELÂL ŞENGÖR§ \\ *Department of Sedimentology \& Environmental Geology, Geoscience Center, University of \\ Göttingen, Goldschmidtstraße 3, 37077 Göttingen, Germany \\ $\$$ School of Geography, Geology and the Environment, Keele University, Keele, Staffordshire \\ ST5 5BG, UK \\ $\S$ Eurasia Institute of Earth Sciences and Department of Geology, Faculty of Mines, Istanbul \\ Technical University, Ayazağa, Istanbul 34469, Turkey
}

†Author for correspondence: g.meinhold@keele.ac.uk

Abstract: Palaeogeography is the cartographic representation of the past distribution of geographic features such as deep oceans, shallow seas, lowlands, rivers, lakes and mountain belts on palinspastically restored plate tectonic base maps. It is closely connected with plate tectonics which grew from an earlier theory of continental drift and is largely responsible for creating and structuring the Earth's lithosphere. Today, palaeogeography is an integral part of the Earth sciences curriculum. Commonly, with some exceptions, only the most recent state of research is presented; the historical aspects of how we actually came to the insights which we take for granted are rarely discussed, if at all. It is remarkable how much was already known about the changing face of the Earth more than three centuries before the theory of plate tectonics, despite the fact that most of our present analytical tools or our models were unavailable then. Here, we aim to present a general conspectus from the dawn of 'palaeogeography' in the 16th century onwards. Special emphasis is given to innovative ideas and scientific milestones, supplemented by memorable anecdotes, which helped to advance the theories of continental drift and plate tectonics, and finally led to the establishment of palaeogeography as a recognized discipline of the Earth sciences.

Keywords: palaeogeography, continental drift, plate tectonics, Earth history. 


\section{Introduction}

Palaeogeography (spelt paleogeography in American orthography) deals with the reconstruction of physical geographical conditions of the past of the Earth. Palaeogeographic changes profoundly influence ocean circulation patterns and ocean chemistry, climate, biological evolution, and the formation and distribution of mineral and hydrocarbon resources. Palaeogeographical research is therefore essential for understanding the evolution of our planet better and for the exploration of raw materials to meet the world's needs in the future. The term 'palaeogeography' comes from the Greek $\pi \alpha \lambda \alpha$ ió $\varsigma$ (palaiós) meaning 'old' and $\gamma \varepsilon \omega \gamma \rho \alpha \varphi$ ía (geōgraphía) meaning 'a description of the Earth' and was introduced in Earth sciences vocabulary as 'paleogeography' by Thomas Sterry Hunt (1826-1892), an American geologist and chemist, in his publication The Paleogeography of the North-American Continent (Hunt, 1873, p. 417). The first mention of the term 'Palaeo-Geographie' in German was by Ami Boué (1794-1881), a French-Austrian geologist, in his publication Einiges zur palaeo-geologischen Geographie (Boué, 1875, p. 305). The first mention of the term 'palæogeography' in British English was by Robert Etheridge (1819-1903), an English geologist and palaeontologist, in his anniversary address as president of the Geological Society of London (Etheridge, 1881, p. 229). Palaeogeography focuses on the distribution of land and sea, the distribution of mountains and volcanoes, and the expansion of glaciations, among others. The results are presented in geographic depictions called palaeogeographic maps. A special kind of palaeogeographical map is palaeobiogeographical maps, depicting the distribution of organisms at a chosen interval in the past. Palaeogeographical maps are not to be confused with palaeogeological maps that are defined to be geological maps of rocks immediately below the surface of an unconformity (e.g. Levorsen, 1960). Performing palaeogeographic analysis requires a thorough understanding of the geological processes that affected a specific study area (e.g. see the discussion in Beuerlen, 1968). How do we know the position of continents going back through geological time? For that, palaeogeographers use much the same kind of data as, for example, Wegener (1915) did, that is, comparing similar rock formations, analysing the distributions of fossil fauna and flora, and looking for evidence of ancient climate signals preserved in the rock record. More precise data on the geographic position of continental plates can be obtained by studying remnant magnetism in rocks, among others (e.g. van der Voo, 1993; Torsvik \& Cocks, 2017). Ocean-floor magnetic 
anomalies (since the Jurassic) (Cande et al. 1989) and fracture zone orientations provide much more precise displacement paths of the major continental rafts on Earth. Because of the amount of data handled and different techniques applied, palaeogeography is probably one of the most complicated Earth science disciplines.

The need to understand the changing face of the Earth goes back more than 2500 years (Toula, 1908). The Greek thinker Anaximander of Miletus (fl. early 6th century BC) proposed a wider distribution of the oceans across the land in prehistoric time based on his findings of fossilized marine molluscs on land. Anaximander's 'student' Xenophanes of Colophon (c. 570-475 BC) and Herodotus (c. 484-425 BC), the historian from Halicarnassos, also in Asia Minor, entertained similar ideas. The Greek philosopher and scientist Aristotle (384-322 BC) assumed rhythmic, very slow changes of the land-sea distribution. After some brief flare-up of these thoughts during the Renaissance, they were once more subjects of discussion in the 18th and 19th centuries (see Şengör, 2003).

Scientists such as Jean-Baptiste Lamarck, Georges Cuvier, Charles Darwin and others suggested that life had changed throughout Earth's history, and that new species had repeatedly arisen and disappeared (e.g. Cuvier, 1825; Darwin, 1859). The collection of fossils was common practice and in vogue during this time. However, the collectors were often puzzled why an ancient animal of obviously marine origin was found far away from the sea and sometimes even on top of a mountain, or how could fossils of the same species be found on different continents? A major obstacle to answering these and other questions was the assumption that the continents and oceans were stable and unchanging (e.g. Dana, 1863, pp. 731-732), relying on a 'fixist' view of the world. Until the 18th century, most Europeans thought that a Biblical Flood played a major role in shaping the Earth's surface (Kious \& Tilling, 1996). This way of thinking was known as 'catastrophism', and geology - from the

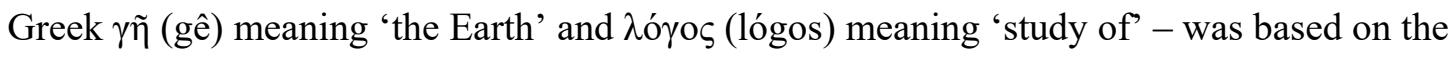
belief that all changes on Earth were sudden and caused by a series of catastrophes.

By the mid-19th century, however, catastrophism gave way to 'uniformitarianism', a new way of thinking centred around the 'Uniformitarian Principle', sometimes also referred to as the 'Principle of Uniformity', proposed in 1785 by James Hutton (1726-1797), a Scottish farmer, chemist and naturalist. This principle is today well known among geologists 
and often expressed as 'the present is the key to the past'. Hutton published his ideas in Theory of the Earth (Hutton, 1788), among other publications. Hutton's work was widely popularized by John Playfair (1748-1819), a Scottish scientist and mathematician, in his book Illustrations of the Huttonian Theory of the Earth (Playfair, 1802). Hutton's ideas were widely used and developed, particularly by Scottish geologist Charles Lyell (1797-1875) in his three-volume book Principles of Geology (Lyell, 1830-1833). Lyell persuasively advocated 'uniformitarianism' (Baker, 1998). Lyell's work, in turn, strongly influenced Charles Darwin as he developed his theory of evolution (Darwin, 1859). For these reasons, James Hutton is now widely regarded as 'the Founder of Modern Geology' (see especially Şengör, 2001).

Additional note on the word geology: the term 'giologie' (as written in the original version) was first proposed almost in its modern sense in 1603 by the Italian polymath Ulisse Aldrovandi (1522-1605) in his testament (first published in 1774). It was later used by Michael Peterson Escholt (?-1666) in his Geologica Norvegica in 1657, by Erasmus Warren (?-1718) in his Geologia: or, a Discourse Concerning the Earth before the Deluge (1690) and then in 1778 by the philosopher and meteorologist Jean-André de Luc (or Deluc) (17271817), a native and citizen of the Protestant city-state of Geneva (not yet incorporated into Switzerland); de Luc apologized for not adopting the term because 'it was not a word in use' (Freshfield, 1920, p. 442). One year later, Horace-Bénédict de Saussure (1740-1799), a Swiss meteorologist, physicist, geologist, mountaineer and Alpine explorer, introduced the term 'geology' (and 'geologist') in the literature in Volume 1 of his book Voyages dans les Alpes (translated into English as Travel in the Alps) (de Saussure, 1779; see also Freshfield, 1920, p. 442). In the German-speaking countries in particular, the term 'Geognosie' (English: geognosy) - from the classical Greek $\gamma \tilde{\eta}$ (gê) meaning 'the Earth' and $\gamma v \tilde{\omega} \sigma 1 \varsigma$ (gnósis) meaning 'knowledge'), introduced by Georg Christian Füchsel (1722-1773) and later made popular by Abraham Gottlob Werner (1749-1817) - long rivalled geology as the name of the Earth science; it gradually fell out of general use in the first quarter of the 19th century however (although in Germany it's use as a descriptive part of geology lasted until the 20th century).

With time, scientists recognized that the old doctrine of 'fixism' that did not allow large horizontal motions of continents on the surface of the Earth must be replaced by the theory of 
'mobilism' (Argand, 1924). In the first quarter of the 20th century, the theory of continental drift was introduced and later replaced by the theory of plate tectonics. Plate tectonic processes are responsible for the changes in Earth's geography. They influence nearly all geological processes, but it took some time and effort to convince the scientific community of this revolutionary theory. The plate tectonics paradigm celebrated its 50th anniversary in 2015, founded on the publication by J. Tuzo Wilson (1965). It is however remarkable how much was already known about the changing face of Earth more than three centuries before the plate tectonics paradigm, despite the fact that most of our present analytical tools or our models were unavailable then. That knowledge was the basis from which great minds developed their fundamental interpretations. The following sections provide a historical approach with special emphasis on innovative ideas and scientific milestones for the development of the theory of continental drift superseded by the theory of plate tectonics, which finally led to the establishment of the modern phase of palaeogeography. The authors are aware of the fact that a detailed review on this subject could easily fill some hundreds of pages due to the wealth of published literature (Fig. 1); in this article only the most important facts - based on the authors' choice - are reviewed however, and the readers are referred to the cited literature for further information.

\section{Gradual onset of the awareness of continental mobility}

The idea that continents have not always been fixed in their present positions and might have 'drifted' had been put forward three centuries before Alfred Wegener presented his theory of continental drift. The Flemish cartographer and geographer Abraham Ortelius (1527-1598) discussed Plato's Atlantis legend in the third edition of his Thesaurus Geographicus. Ortelius (1596) suggested that Plato had described an ancient separation of the continents, and used this interpretation to account for the matching coastlines of the Old and New Worlds (Romm, 1994). He suggested that the Americas were 'torn away from Europe and Africa ... by earthquakes and floods' and that 'the vestiges of the rupture reveal themselves, if someone brings forward a map of the world and considers carefully the coasts of the three [continents]' (Ortelius, 1596). He noticed that the east coast of South America and the west coast of Africa could fit together perfectly, like a jigsaw if they were just closer, or if the Atlantic Ocean was closed. He also recognized that the continents were moving as 
can be seen by his statement 'torn away from Europe and Africa ... by earthquakes and floods'. Ortelius used for his idea a world map, which he published in 1570 in his atlas Theatrum Orbis Terrarum (Ortelius, 1570). Unfortunately, Ortelius was living a few centuries too early and his innovative idea was not further explored till the 19th century.

Commonly, the credit is given to Francis Bacon (1561-1626), an English philosopher, scientist, statesman and jurist, for being the first to have observed the jigsaw fit of the opposite coasts of Africa and South America. In his book Novum Organum, published in 1620, Bacon wrote about the Old and New Worlds as examples of 'conformable instances' (Carozzi, 1970; Romm, 1994). This assumption, however, is evidently false, as pointed out by Davies (1965) and Carozzi (1970). The shape of the two continents is mentioned, but only briefly in Aphorism XXVII of Novum Organum, Lib. II. Bacon says that the Old and New Worlds both taper southwards, and that Africa and South America display a further general similarity in their outlines. It seems he did not compare the opposite coasts of the two continents, but rather noted how their west coasts were similar in outline (Davies, 1965; Carozzi, 1970). Bacon offers no discussion of the subject, but it appears that he was merely suggesting that a feature such as the 'horn' of East Africa may be likened to the 'shoulder' of Brazil, or the Gulf of Guinea to the Peru-Chile bight (Davies, 1965).

There has been a continuing flow of ideas regarding the former geographic connection between the Old and New Worlds. In 1650, the German geographer Bernhardus Varenius (1622-1650/51?) remarked in his book Geographia Generalis that formerly America and Europe had been a single continent. He wrote that America was later torn from Europe and that the American Indians were therefore also children of Adam (Varenius, 1650, p. 333). The impression that Varenius (1650) was probably aware of the work by Ortelius (1596) is given, but this is speculation by the authors.

Others have noted that the shapes of the continents on opposite sides of the Atlantic Ocean, most notably Africa and South America, seem to fit together. Theodor Christoph Lilienthal (1717-1781), a Königsberg Lutheran theologian, is thought to have discovered in the Bible the supposed confirmation of a break-up of the continents following Noah's flood through which the Atlantic Ocean formed. He founded his idea, among others, on the Bible verse 25 in Chapter 10 of Genesis 'two sons were born, one was called Peleg, because in his 
time the earth was divided'. The most intriguing part is following: 'Pliny testifies that formerly many countries have been separated by the sea from each other. This is also probable by the fact that the opposite coasts, though separated by the sea from each other, have a corresponding outline, so that they would almost fit together, as if they were next to each other, for example, the southern part of America and Africa' (Lilienthal, 1756, p. 247).

Alexander von Humboldt (1769-1859), the celebrated Prussian geographer (considered one of the two founders of the modern science of geography, the other being his friend Carl Ritter), naturalist and explorer, and certainly one of the most famous scientists of this time, summarized his vast range of knowledge in the several volumes of the Kosmos: Entwurf einer physischen Weltbeschreibung (translated into English as Kosmos: A general survey of the physical phenomena of the universe). In Volume 1, he wrote 'Our Atlantic Ocean bears every feature of a great valley. It is as if floods had directed their shocks successively to the north-east, then to the north-west, and then to the north-east again. The parallelism of the opposite coasts northward from $10^{\circ}$ of S. latitude, their advancing and retreating angles, the convexity of the shores of Brazil opposite those of the Gulf of Guinea, the convexity of Africa under the same parallels of latitude as the deep indentation formed by the Gulf of Mexico, all vouch for this apparently bold view. In this Atlantic valley, as almost everywhere else in the configuration of great masses of land, indented and isle-studded shore stand opposite to unindented coasts. It is long since I directed attention to the circumstance how remarkable in a geological point of view was the comparison of the west coasts of Africa and South America within the tropics' (von Humboldt, 1845a, p. 314; for the corresponding German version see von Humboldt, 1845b, p. 309; von Humboldt had first published his ideas on the comparable opposing coasts of the Atlantic in von Humboldt, 1804, pp. 404405). Earlier, he also noted to his astonishment that orientations in the rocks of old mountain ranges in Italy, France, Switzerland, Germany and Poland are similar to those observed in the mountains in northern South America (von Humboldt, 1801, p. 333) but, as we know today, it seems he compared rocks and mountain ranges of different ages.

In 1857 Richard Owen (1810-1890), professor of chemistry and geology in Nashville, Tennessee, USA, published the idea that the entire American continent had once formed an upper layer on top of the western part of the Old World and had slid off it to open the Atlantic Ocean. He wrote '... in order to bring the hypogene rocks of America and those of northern 
Europe to form a regular curve ... we must not only bring the two continents in actual contact, but we must slide a portion of North America into western Europe, the northern mass of South America on to the great Sandy Desert of Sahara, when sunk ... beneath the waters of the ocean ...' (Owen, 1857, p. 75). Owen also noted 'The earth's crust, thus expanded and disrupted, separated, sometimes vertically, entirely through all its deposited layers, sometimes ... by horizontal removal of an upper layer, leaving a lower layer, or vice versa: this may explain ... various geographical peculiarities. When we restore the parts supposed disrupted ... then we find geological formations, as well as geographical mountain-chains, etc., fitting into their original positions' (Owen, 1857, p. 225). Overall, Owen's observations and descriptions may be regarded as the first promising steps towards palaeogeographic reconstructions as he considered geological evidence, among other things.

Antonio Snider-Pellegrini (1802-1885), dit Antonio Snider, a French geographer and scientist, proposed in his La création et ses mystères dévoilés (translated into English as The creation and its mysteries unveiled) that all of the continents were once connected together during late Carboniferous time (Fig. 2) and that the Atlantic had been rifted open during the Biblical Flood (Snider, 1859, pp. 307-315). None of the above-mentioned theories found an audience among the Earth sciences community, however.

Austrian geologist Eduard Suess (1831-1914), was, among others, an expert on the Alps. He gradually developed views on the connection between Africa and Europe and came to the conclusion that the Alps to the north were once at the bottom of an ocean, of which the Mediterranean was a remnant. He is credited with discovering the Tethys (often referred to as the Tethys Ocean), which he named in 1893 after the Titan Tethys, the daughter of Uranus and Gaia and the sister and consort of Oceanus, the ancient Greek god of the ocean (Suess, 1893). His other major discovery was that the Glossopteris flora - an extinct group of seed ferns that arose during Permian time but became extinct by the end of the Triassic Period were found in South America, Africa, India and Australia. His explanation was that the three lands were once connected into a supercontinent, which he named originally Gondwana-Land (proposed in 1885) (from the Sanskrit gondavana meaning 'forested (land) of the Gonds'), a historic region in central India. Note that the name Gondwana had already been introduced into geological vocabulary in 1872 by the Irish geologist Henry Benedict Medlicott (18291905) who served as Director of Geological Survey of India from 1876 to 1887 (see Leviton 
$\&$ Aldrich, 2012). The name was used for the stratigraphic Gondwana system of India (Medlicott \& Blandford, 1879). Eduard Suess believed that the oceans flooded the spaces currently between those lands when the pieces in between sank. He published a comprehensive synthesis of his ideas in three volumes in five parts (Suess, 1883, 1885, 1888, 1901, 1909) entitled Das Antlitz der Erde (translated into English as The Face of the Earth), one of the most fundamental texts of modern geology. Suess also coined the terms Laurentia, Caledonian Mountains, Variscan Mountains, Panthalassa, biosphere, lithosphere, hydrosphere, eustasy, foreland, hinterland, listric fault, horst and graben, today part of the established Earth sciences vocabulary and closely connected with plate tectonics and palaeogeography (see Şengör, 2014a, 2015).

\section{The rise of the theory of continental drift}

It was not until 1912 that the idea of lateral mobility of continents was seriously considered - at least by a few masterminds - as a scientific theory called 'Kontinentalverschiebung' (as written in the original version), translated into English as 'continental drift'. The German meteorologist Alfred Wegener (1880-1930) presented his theory to the public for the first time in a lecture entitled Die Heraushebung der Großformen der Erdrinde (Kontinente und Ozeane) auf geophysikalischer Grundlage (translated into English as The uprising of large features of earth's crust (Continents and Oceans) on geophysical basis) at the annual general meeting of the Geologische Vereinigung on 6 January 1912 in Frankfurt am Main (Wegener, 1912a, b) in the Senckenberg Museum lecture hall (where a plaque to that effect now hangs). Wegener suggested that continents were joined together at one time. Thereafter, they moved through the Earth's simatic crust like icebreakers ploughing through sea ice, finally reaching their present position. His theory centred around the hypothesis that the continents consist of a lighter assemblage of elements called Sal - an acronym of silicon and aluminium, introduced by Eduard Suess in the last volume of Das Antlitz der Erde - which isostatically float on a heavier assemblage of elements of the Earth's outer mantle called Sima - an acronym of silicon and magnesium (Fig. 3); today, Sal is called sial.

Frankly speaking, much of what he proposed was not completely new because he based his idea on earlier observations and suggestions. It was however topped by a broad array of 
newly collected evidence, and his theory initiated a lively discussion among scientists. For example, he wrote 'The first concept of continental drift first came to me as far back as 1910, when considering the map of the world, under the direct impression produced by the congruence of the coastlines on either side of the Atlantic. At first I did not pay attention to the idea because I regarded it as improbable. In the fall of 1911, I came quite accidentally upon a synoptic report in which I learned for the first time of palaeontological evidence for a former land bridge between Brazil and Africa. As a result, I undertook a cursory examination of relevant research in the fields of geology and palaeontology, and this provided immediately such weighty corroboration that a conviction of fundamental soundness of the idea took root in my mind' (Wegener, 1929, p. 1; for the English translation see Wegener, 1966, p. 1). He published the core idea of 'continental drift' first in two papers (Wegener, $1912 a, b)$ and then in the first edition of his book Die Entstehung der Kontinente und Ozeane (translated into English as The Origin of Continents and Oceans) (Wegener, 1915), followed by three revised editions (Wegener, 1920, 1922 and 1929) which each contained new data.

One of the basic concepts that helped Wegener document the continental drift was the idea of a large united landmass consisting of most of the Earth's continental regions. In his theory, Wegener introduced the supercontinent of Pangaea (derived from $\pi \tilde{\alpha} v \mathrm{MS}-\gamma \alpha \boldsymbol{i}_{\alpha}$, Greek for 'all earth') to explain the ancient climate similarities, fossil evidence and similarity of rock structures between Africa and South America, as well as the outlines of the continents, especially the continental shelves, which seem to fit together (Fig. 4). Wegener used the following geological evidence, among others, to support his theory. (1) Similar rock types were found in mountain ranges on either side of the Atlantic Ocean, for example the Appalachian Mountains of northeastern North Americas linked to the Scottish Highlands and those south of New York to the Hercynides of France and Spain. (2) Similar (or closely related) fossils were found on either side of the Atlantic Ocean, implying that the continents were once joined together. (3) Fossil tropical land plants were found in rocks which are now in the polar regions; in 1912, Glossopteris was found in Antarctica (e.g. Osborne, Royer \& Beerling, 2004) during the famous and ill-fated Terra Nova Expedition (British Antarctic Expedition between 1910 and 1913) with the British Royal Navy officer and explorer Captain Robert Falcon Scott (1868-1912) as its leader. 
Wegener's theory of continental drift was either ignored or downright ridiculed by the scientific community (e.g. Soergel, 1916; Andrée, 1917; Kossmat, 1921; Penck, 1921; Schweydar, 1921; Jaworski, 1922; Nölke, 1922). The Americans were particularly adamant; Bailey Willis (1944) called Wegener's theory 'ein Märchen' (a fairy tale) and Oreskes (1999) provided several reasons for the American rejection. First, Wegener was not a geologist by profession, which of course was most welcome by his opponents. Secondly, most influential geoscientists at that time were based in the Northern Hemisphere, whereas most of the conclusive data came from the Southern Hemisphere. Thirdly, Wegener thought that Pangaea did not break up until Cainozoic time, and palaeontologists found it hard to believe that so much continental drift could have occurred in so short a time. Last but not least, the greatest problem remained the lack of direct evidence for the movements of continents and the needed explanation for the mechanism. Wegener thought the force of Earth's spin was sufficient to cause continents to move, but geophysicists knew that rocks are too strong for this to be true. Wegener also thought that the continents were moving through the Earth's simatic crust, like ice-breakers ploughing through sea ice (Fig. 3). Geologists noted that ploughing through oceanic crust would distort continents beyond recognition, and geophysicists could not think of a force strong enough to make continents able to plough through oceanic crust.

Consequently, Wegener's theory of continental drift is in many aspects erroneous because it is not the individual continents which move, but the entire plates of the lithosphere, and the driving forces of slab pull and ridge push (Forsyth \& Uyeda, 1975) come from within the Earth. The movement of plates is not driven by the rotation of the Earth. Wegener's theory was heavily attacked by most of the Earth scientists of this time. Wegener was unable to obtain a regular professorship at any of the universities or technical high schools in Germany because he was 'interested also, and perhaps to a greater degree, in matters that lay outside its terms of reference' (Horvitz, 2002, p. 162). The University of Graz in Austria was more tolerant of controversy and, in 1924, appointed him professor of meteorology and geophysics. Regardless of the controversies mentioned above, perhaps Wegener's most important legacy is to have introduced the idea of lateral mobility of continents, that is, offering a paradigm change from fixism to mobilism to the scientific community and the public. Overwhelmingly, however, most of the established geologists were convinced that the Earth's continents were immobile and neglected Wegener's foresighted approach. 
One of Wegner's staunchest supporters was the South African geologist Alexander Logie du Toit (1878-1948); Reginald Aldworth Daly considered him the greatest field geologist of the 20th century. In 1923, du Toit was awarded a Carnegie Institute grant to travel to South America to test his thesis that rock formations in South Africa have their counterparts in Brazil. They indeed do, convincing him that African and South American continents had once been joined and have drifted apart (Fig. 5). He published his observations in the Publication of the Carnegie Institution of Washington entitled A Geological Comparison of South America with South Africa (du Toit, 1927; a slightly expanded version in Portuguese was published posthumously in 1952 in Brazil, du Toit, 1952), and later he developed his ideas in Our Wandering Continents: An Hypothesis of Continental Drifting (du Toit, 1937). du Toit (1937) proposed that Wegener's Pangaea first broke into two large continental landmasses: Laurasia in the Northern Hemisphere and Gondwana-Land (which du Toit inappropriately shortened to Gondwana) in the Southern Hemisphere. Laurasia and Gondwana-Land then continued to break apart into the various smaller continents that exist today.

Another strong supporter of Wegener's theory of continental drift was Boris Choubert (1906-1983), a French geologist of Russian origin. He was the first scientist to present a very accurate geometrical fit of the circum-Atlantic continents using continental edges instead of coastlines (Choubert, 1935) (Fig. 6a); this was remarkably like the oft-cited 'Bullard fit' reconstructed 30 years later (Fig. 6b), further demonstrating that the continents were closely jointed together at one time. Choubert interpreted the Precambrian and the Palaeozoic ('Caledonian' and 'Hercynian') belts as the result of horizontal movements of the Precambrian blocks. This pioneer was however overlooked for many years, as pointed out by van Houten (1975). Kornprobst (2017) analysed the lack of recognition of Choubert's work and came to the conclusion that it was related to a great evolution in the geological concepts between 1935 and 1965, and the poor choice of Choubert regarding the title of his 1935 publication. Some scientists have been aware of this unfairness in the recognition of Choubert's work. At a scientific meeting at the beginning of the 1970s, the French geophysicist Xavier Le Pichon, one of the pioneers of plate tectonics, proposed that the circum-Atlantic continents fit should be called the 'Bullard-Choubert fit' (Kornprobst, 2017, p. 48). Although this proposal was not further considered by the scientific community, it 
should be on the agenda of forthcoming international scientific meetings as the great work of Boris Choubert should be honoured in some way. Choubert's geological and palaeogeographical work was also analysed by Şengör (2014b) and Letsch (2017), and highlights once more Choubert's masterpieces of Earth sciences research before the emergence of the theory of plate tectonics.

Reginald Aldworth Daly (1871-1957), a Canadian igneous petrologist and a highly regarded geology professor at Harvard University, was also a proponent of Wegener's theory. Daly expressed his support by putting E pur si muove! (translated into English as And yet, it moves!) on the title page of his book Our Mobile Earth (Daly, 1926).

\section{Transition from continental drift to plate tectonics}

Wegener's theory of continental drift (Wegener, 1912a, $b, 1915)$ became the spark that ignited a new way of viewing the Earth that led some scientists to start searching for an explanation of how continents could move. Robert Schwinner (1878-1953), an Austrian geologist and geophysicist, had revived an old idea of von Humboldt's that convective magma flows might exist in the mantle and that the continents are riding on the back of those slow convective current streams (Schwinner, 1920, 1941). The Austrian geologist Otto Ampferer (1875-1947) had a similar idea, and probably presented the first model of convection currents being responsible for continental drift (Ampferer, 1925) (Fig. 7). As early as in 1916 and later in 1928 the Dutch geologist Gustaaf Adolf Frederik Molengraaf (1860-1942) identified the mid-Atlantic ridge as a volcanic structure, and argued that a locus of ocean-floor spreading was separating the continents on both sides of the Atlantic (see Molengraaf, 1916, 1928). Ampferer followed his lead in a remarkable paper in 1941 entitled Gedanken über das Bewegungsbild des atlantischen Raumes (Ampferer, 1941; see also Thenius, 1988). Likewise, Arthur Holmes (1890-1965), a British geologist who early on realized the great potential of Lord Rutherford's discovery in 1911 that radioactivity provided a means to measure the ages of minerals (Holmes, 1913, 1946), came up with an explanation for why continents could move, but it was more advanced than the theories of Schwinner and Ampferer. Holmes suggested that heat trapped in the Earth's mantle caused vast, slowmoving convection currents and that this was the power source that Wegener needed to make the continents drift (e.g. Holmes, 1928, 1931, 1944). In the famous first edition of his book 
Principles of Physical Geology, he shows a drawing of mantle convection and wrote 'Currents flowing horizontally beneath the crust would inevitably carry the continents along with them' (Holmes, 1944, p. 506). He also suggested '... the currents ... drag the two halves of the original continent apart, with consequent mountain building in front where the currents are descending, and ocean floor development on the site of the gap, where the currents are ascending' (Holmes, 1944, p. 506). The last statement refers to mid-ocean ridges; their discovery was another milestone in Earth sciences that contributed towards the theory of plate tectonics, which steadily replaced the theory of continental drift. But when, how and by whom was the discovery of mid-ocean ridges made?

In 1850 Matthew Fontaine Maury (1806-1873), a US Navy lieutenant and an expert of the sea (thus nicknamed 'Pathfinder of the sea'), inferred a ridge in the middle of the Atlantic Ocean while evaluating acoustic soundings acquired with the research vessel Dolphin. He presented his findings in The Physical Geography of the Sea (Maury, 1855). A few decades later, the British vessel HMS Challenger (1872-1876) set off to explore the Atlantic Ocean. The first bathymetric chart of the entire Atlantic Ocean by Murray \& Renard (1891), synthesized from bathymetric data acquired during the HMS Challenger expedition, reveals a structure in the middle of the ocean which can be interpreted as a ridge. The sparse acoustic soundings only permitted generalized contours, however; a more detailed outline of the ridge and the ocean floor was still to be made. For that, we shall now move to Germany.

The German chemist Fritz Haber (1868-1934), who was awarded the Nobel Prize in Chemistry in 1918 (received in 1919), suggested that Germany could ease its war debts after World War I by extracting gold from seawater (Mero, 1965, p. 41). This suggestion was based on the assumption that gold was in seawater in concentrations of 5-10 mg of gold per ton of seawater (Haber, 1927, p. 303). Haber was therefore secretly assigned to extract gold from the sea, 'a dream of generations of scientists' (Broad, 1997, p. 252). In 1925, the legendary German research vessel Meteor set out in great secrecy to systematically explore the Atlantic Ocean from the Antarctic region to the tropics of the North Atlantic. Huge volumes of seawater were examined for information on water chemistry and temperature, and some 67000 acoustic soundings were conducted. After two years of study, they returned with the data. Haber found that the sample from the Meteor's cruise had a mean gold content of $0.008 \mathrm{mg}$ of gold per ton of seawater (Haber, 1927, p. 310); he therefore failed as there is 
much less gold in seawater than earlier assumed. However, the expedition identified in great detail a long ridge running along the middle of the Atlantic Ocean as illustrated on the first detailed bathymetric chart of the South Atlantic (Maurer \& Stocks, 1933), which was incorporated into the Atlantic bathymetric map of the time by Stocks \& Wüst (1935). The identified ridge later became known as the Mid-Atlantic Ridge (Heezen, Tharp \& Ewing, 1959). It is a mid-ocean ridge, that is, a mountain range on the floor of the Earth's oceans, an important key to the theory of plate tectonics.

Much was speculated about the origin of the mid-ocean ridges until the American geologist Harry Hess (1906-1969), who conducted extensive sea-floor mapping during World War II, published a ground-breaking paper entitled History of Ocean Basins (Hess, 1962) in which he developed his idea of sea-floor spreading, a forerunner of plate tectonics. He reinvented Molengraaf's idea that the sea floor forms at the mid-ocean ridge and moves horizontally from the ridge crest towards an oceanic trench, where it is subducted into the mantle. Convection in the mantle is the driving force for this process. One year earlier, Dietz (1961) had proposed a concept referred to 'spreading sea-floor theory'; his argumentation was not necessarily independent however (as Hess' manuscript had been circulating in scientific circles since 1959), and was not as detailed as that by Hess (1962). From the 1950s onwards the world's oceans were extensively investigated with magnetometers, among others. Magnetic anomalies arranged in linear patterns on the seafloor subparallel with respect to the ocean-spreading ridges were identified, first on the sea floor off California (Mason, 1958; Mason \& Raff, 1961) and later in other ocean basins. Lawrence Morley (his paper was rejected by Nature) and Vine \& Matthews (1963) were the first to recognize their importance and present an explanation for these linear pattern, which developed due to numerous reversals in the Earth's magnetic field. Each magnetic stripe was magnetized when that piece of ocean floor was formed in the central valley on the mid-ocean ridge axis.

In the light of these new discoveries, a better understanding of how the Earth seems to work was on its way. Some scientists were however sceptical with the convection current hypothesis as the main driver of sea-floor spreading, and instead favoured a general expansion of the Earth (e.g. Heezen \& Tharp, 1965; Oppenheim, 1967). Nevertheless, a reevaluation of Wegener's theory of continental drift, the movements of the continents and 
their arrangements through geological time became once more a topic of interest among the scientific community (e.g. Carey 1955, 1958).

The first computational approach in palaeogeography was presented by Sir Edward Bullard (1907-1980), Jim E. Everett and Alan G. Smith (1937-2017) in their famous paper 'The fit of the continents around the Atlantic' (Bullard, Everett \& Smith, 1965), which shows a very accurate geometrical fit of the circum-Atlantic continents using the early Cambridge University EDSAC 2 computer. They used the real 'edge of the continent', that is, the continental margin instead of the coastlines (Fig. 6b). This fit became known as the 'Bullard fit' (Bullard, 1969), although much of the work was done by the co-authors (Bullard, 1975, p. 21). Although they were concerned only with the kinematic approach and were not discussing the mechanism by which continents split and oceans formed, the paper by Bullard, Everett \& Smith (1965) can be seen as a linking transition between the theories of continental drift and plate tectonics (Dewey, 2015). With the immense knowledge gained in the 1950s and early 1960s, including Wilson's 'hot spots' hypothesis (Wilson, 1963), all foundation stones for the forthcoming plate tectonics theory had been laid out.

\section{Flourishing of the plate tectonics paradigm}

The plate tectonics theory celebrated its semi-centennial in 2015. It was introduced by the Canadian geophysicist and geologist John Tuzo Wilson (1908-1993) in a groundbreaking paper in Nature in 1965, in which he defined the nature of the plates and plate boundaries and discussed the continuous motion of rigid plates with respect to one another (Wilson, 1965) (Fig. 8). Unknowingly following Argand (1924), Wilson (1966) suggested the existence of a proto-Atlantic Ocean prior to the late Palaeozoic assembly of the Pangaea, and that the ocean must have closed before Carboniferous time and later re-opened to form the present-day Atlantic Ocean (such repeated opening and closing of an ocean basin came to be known as the 'Wilson Cycle', a term coined by Kevin Burke in Burke \& Dewey, 1973). The papers of McKenzie \& Parker (1967), Sykes (1967), Morgan (1968), Le Pichon (1968) and Isacks, Oliver \& Sykes (1968) were seminal in providing diverse tests of the theory and their successful tests helped to establish it as the unifying theory of tectonics. The motions of the rigid plates were described as rotations across Earth's spherical surface by defining poles, known as Euler poles. Publications on plate tectonics flourished in the following years (e.g. 
Dewey, 1969a, b; Hamilton, 1969, 1970; Laubscher, 1969; Mitchell \& Reading, 1969; Bird \& Dewey, 1970; Dewey \& Bird, 1970a, b, 1971; Dickinson, 1971a, b; Wilson, 1972; Marvin, 1973; Tarling \& Runcorn, 1973; Dewey, 1975; Cox \& Hart, 1986; Davies, 1992). By the early 1970s, the term 'plate tectonics' was well established in the Earth sciences vocabulary. Today, the Earth's lithosphere is divided into seven large and a few smaller plates. The plates move slowly at a rate of a few centimetres per year and change size. Plates may be entirely made up of continental rocks, both continental and oceanic rocks, or entirely of oceanic rocks. Continental plates on Earth appear to have a tendency to episodically assemble, disperse and re-assemble in various supercontinental configurations (e.g. Dewey, 1988; Nance, Murphy \& Santosh, 2014), although these peculiarities are still under debate (e.g. Bradley, 2011).

Following Hutton's 'Principle of Uniformity', plate tectonics must be ongoing for at least three billion years, if not more. However, the onset of plate tectonics is still a hot topic of scientific discussion and a few comprehensive reviews have already been written (e.g. Condie \& Pease, 2008). Some believe that the onset of modern-style plate tectonics on Earth began in the Neoproterozoic Period, documented by the first appearance of high-pressure, low-temperature rocks such as oceanic blueschists and low-temperature eclogites, and ultrahigh-pressure intracontinental complexes and kimberlite diatremes (Stern, 2005; Stern, Leybourne \& Tsujimori, 2016). There is, however, a growing consensus that plate tectonics in general started much earlier (see de Wit \& Ashwal, 1997; Harrison et al. 2005; Cawood, Kröner \& Pisarevsky 2006; Polat, Kerrich \& Windley, 2009; Korenaga, 2013). During 3-2 Ga the Earth record shows some fundamental geological and geochemical changes, which may be an expression of the cooling of the Earth's mantle and corresponding changes in convective style and the strength of the lithosphere, and they may record the gradual onset and propagation of plate tectonics (Condie, 2016). Based on hafnium isotopes (Harrison et al. 2005) and data from experimental petrology (Hastie et al. 2016), it is suggested that the first continents had formed at c. $4 \mathrm{Ga}$ and that subduction processes were also active. Primitive plate tectonics ('permobile regime': Burke, Dewey \& Kidd 1976) may have started in the Hadean Period soon after the magma ocean solidified (Ernst, Sleep \& Tsujimori 2016; Ernst, 2017), but that is under debate (e.g. Stern, Leybourne \& Tsujimori, 2017). Regardless of 
these controversies, plate tectonics has been ongoing for a long period of time, changing the face of the Earth and thus providing the working base for studying Earth's palaeogeography.

\section{Palaeogeographic studies before plate tectonics}

Most of the palaeogeographic work before the rise of plate tectonics was centred on the description of the rock record, including its fossil content, and was confined to showing the distribution of lands and seas on modern base maps. In the early days, the presentation of palaeogeography simply meant illustrating palaeofacies changes through time. To the authors' knowledge, the earliest scientific palaeogeographic map is by the French naturalist Jean Honoré Robert de Paul de Lamanon, dit Robert de Lamanon (1752-1787). De Lamanon (1782) studied some vertebrate fossils from the gypsum quarries of Montmartre in Paris, and decided that the gypsum was deposited in lakes and not in the sea on the basis of the fossils he considered. He then established the horizontal limits of the gypsum, which he assumed had been those of the former lake. Figure 9 shows his palaeogeographical map of Montmartre at the time of the existence of the lake. De Lamanon had no means of dating his lake. He only knew that some of the animals that lived in it no longer existed, and thus the lake must have existed before the present fauna was established.

In the middle of the 19th century, palaeogeographical studies advanced as shown by the publications of de Beaumont (1833), Lyell (1835), Beudant (1841), Marcou (1857-1860) and Dana (1863). The famous map of Neumayr (1885) showing the geography of the Jurassic Period (Fig. 10) is the most detailed palaeogeographic map of the entire Earth published during the 19th century. In that map, we see not only the distribution of land and sea during the Jurassic Period but also the extent of what Melchior Neumayr (1845-1890), a German palaeontologist from Munich who spent much of his professional life in Vienna working closely with his father-in-law Eduard Suess, called the 'sea of the boreal zone', the 'sea of the temperate zone' and the 'sea of the equatorial zone', indicating the Jurassic climatic zones by the distribution of climate-sensitive rock assemblages and fossils.

The first global palaeogeographical map was not however by Neumayr, but by the French geologist Jules Marcou (1824-1898); Marcou also published a map of the Jurassic Period of the entire world in 1860 (Fig. 11). It was much more primitive than Neumayr's, but 
it was a pioneer attempt. The classical work of Suess $(1883,1885,1888,1901,1909)$ is well known, but Suess produced no palaeogeographic map, confining his descriptions to texts. Other publications worth mentioning are comprehensive works by Koken (1893), Canu (1895) and de Lapparent (1900), just to name a few.

The greatest development of palaeogeographic maps took place during the 20th century, with the previously unimaginable development in the precision of dating rocks and improvement in our knowledge of regional geology including the bottoms of the oceans. Palaeogeography became in vogue among Earth scientists during the first quarter of the 20th century, as shown by the increased number of publications at this time. Willis (1910, p. 241) appropriately noted that palaeogeography 'is a young science that has all its future before it'. Most of the published maps focused on a specific area and certain time slice and, of course, were still following the 'fixist' view (e.g. Matthew, 1906). Theodor Arldt (1878-1960), a German natural scientist, historian and secondary school teacher, presented a collection of palaeogeographic maps from the Cambrian to the Recent periods in his book entitled Die Entwicklung der Kontinente und ihrer Lebewelt (translated into English as The Evolution of Continents and Their Living World) (Arldt, 1907; second edition 1938, of which only the first volume was published because the manuscript of the second volume was destroyed during World War II) (Fig. 12). Toula (1908) presented a thorough discussion about this new approach in palaeogeography. A few years later, Arldt discussed the changing size of continents and oceans and the depths of the ocean basins through time, as well as mountain belts and their relation to the continental margins (Arldt, 1912). In 1914, Arldt provided a first review of palaeogeographical reconstructions (Arldt, 1914). He summarized his vast range of knowledge in two volumes of the Handbuch der Palaeogeographie (Arldt, 19171922) to which we refer, as it contains many references and provides a comprehensive overview of the knowledge from this time. Edgar Dacqué (1878-1945), a German geologist and palaeontologist, also spent much time with palaeogeographic research and summarized his ideas in a number of publications (e.g. Dacqué, 1913) and comprehensive text books such as Grundlagen und Methoden der Paläogeographie (translated into English as Basics and Methods of Palaeogeography) (Dacqué, 1915) and Geographie der Vorwelt (Paläogeographie) (translated into English as Geography of the Past (Palaeogeography)) (Dacqué, 1919). In the Encylopaedia of Geography published by Deuticke in Vienna, Dacqué 
and Wegener published a volume together under the title Paleogeographie, each writing a section (Dacqué, 1926).

The Austrian-German geologist Franz Kossmat (1871-1938) was the first to publish a popular book for the general public simply entitled Paläogeographie (Kossmat, 1908) which went through three editions, the last being in 1924. In his book, he gives an outline of Earth history from the Cambrian Period to the 'Diluvium', supplemented by palaeogeographic maps showing the distribution of lands and seas during the Silurian (Fig. 13), Devonian, Carboniferous, Triassic, Cretaceous and Old-Tertiary periods. Note that the term 'Diluvium' was introduced into literature in 1823 by the English theologian William Buckland (17841856) in his classic book Reliquiae Diluvianae (Buckland, 1823) for the youngest deposits on Earth, considered a product of the Biblical Flood (the 'Diluvial Theory'). Forbes (1846) proposed equating the term 'Pleistocene' - introduced by Lyell (1839, p. 616-621) and commonly referred to as the 'Glacial Epoch' - with the Diluvium. Worth mentioning is also another book by Kossmat related to palaeogeography, entitled Paläogeographie und Tektonik (Kossmat, 1936), in which a comprehensive overview of the relation between palaeogeography and the tectonic structure of the Earth's surface is provided. Different regions of the globe are discussed from the Archean to the Quaternary eras, supplemented by palaeogeographic maps showing the distribution of land and seas in the Cambrian, Devonian, early Carboniferous (Viséan), late Carboniferous, Triassic, Late Cretaceous and middle Eocene periods.

Grabau (1909) presented palaeogeographic maps for North America for the Ordovician, Silurian and Early Devonian periods, and some trans-Atlantic palaeogeographic maps for the early Palaeozoic, which he communicated to the public during the 11th International Geological Congress in Stockholm in 1910 (Grabau, 1912). Willis (1909) also presented palaeogeographic maps for North America (12 time slices). They are too schematic however (Fig. 14), as 'they embrace too much time, and hence do not bring out the oscillatory nature of the continental seas' (Schuchert, 1910, p. 435). Schuchert (1910), an accomplished American palaeontologist and stratigrapher of German descent (he was born in Ohio to German immigrant parents and his mother tongue was German, which enabled him to read with facility the classic geological publications in German), published the first comprehensive review of the palaeogeography of North America, presenting 
palaeogeographic maps for 50 time slices showing the distribution of continental and marine facies (Fig. 15); a compendium of revised maps was present later (Schuchert, 1955).

Discussing the use of fossils for palaeogeographic and palaeoenvironmental reconstructions such as palaeobathymetry was common practice in the early days of palaeogeographic research (e.g. Schuchert, 1911).

With the introduction of Wegener's theory of continental drift, drawing palaeogeographic maps became much more difficult than before because the present-day locations of rock packages with respect to one another, and with respect to the equator, could no longer be taken for granted. In 1922, Wegener published a series of global palaeogeographic maps in the third edition of his book Die Entstehung der Kontinente und Ozeane (Wegener, 1922), which was translated into English and French among some other languages and had the most impact on the geological community. His followers still formed a tiny minority, however. Wishing to be more convincing, Wegener and his father-in-law, the famous climatologist and meteorologist Wladimir Köppen (1846-1940), decided to test Wegenger's reconstructions by using climatologically sensitive rock and plant types in their book entitled Die Klimate der geologischen Vorzeit (Köppen \& Wegener, 1924; see also Köppen, 1940; for a reproduction of the original 1924 German edition and complete English translation see Köppen \& Wegener, 2015). Figure 16a shows the Wegener reconstruction of the continents during the Carboniferous Period, with the climatologically sensitive rock types indicating geographical environments. Figure $16 \mathrm{~b}$ shows the distribution of floras during the Carboniferous and Permian periods.

Probably the first palaeogeographic reconstructions for the Palaeozoic Era, seriously considering continental drift, are those of Choubert (1935) (Figs 17, 18). With time, more text books about palaeogeography and palaeogeographic atlases were published; worth mentioning are those by Kerner-Marilaun (1934), Joleaud (1939), Scupin (1940), Wills (1951) and Termier \& Termier (1960), to name a few. The majority of geologists followed the 'fixist' view until the early 1970s, however, when plate tectonics finally became accepted by the vast majority of Earth scientists.

\section{Palaeogeographic studies after plate tectonics}


Before the introduction of plate tectonics, palaeomagnetic research had made it possible to orientate a piece of rock with respect to the Earth's magnetic pole and to locate it at the latitude on which it had formed (with an error margin of some 500-1000 km). This enabled geologists to know which orientation a continent had and where it roughly was with respect to the equator at a given time in the past. In the 1950s and 1960s, it became more widely accepted than before that Wegener's theory of continental drift was in part correct (for a history of that recognition, see Creer \& Irving, 2012).

After the rise of plate tectonics in the mid-1960s, palaeomagneticians began showing how the various continents or continental pieces had to be placed on the Earth's surface at a given time (e.g. van der Voo \& French, 1974; Irving, 1977, 1988; van der Voo, 1993). Magnetic reversals and the record they leave in the oceanic crust in the form of negatively and positively magnetized stripes paralleling the oceanic spreading centres (e.g. Vine \& Matthews, 1963; Pitman \& Heirtzler, 1966; Cox, 1973), among other data, enable us to track the motion path of continents back to $150 \mathrm{Ma}$ with great precision, and back to $230 \mathrm{Ma}$ with some precision (e.g. Müller et al. 2016).

These developments have gone hand-in-hand in improvements in geologists' understanding of past geographical environments on the basis of the rock and fossil record both on land and at the bottom of the oceans, thanks to a number of international deep-sea drilling programmes. Isotopic dating of rock packages brought a previously unimaginable precision to dating of rocks, making correlations more reliable and more precise. All of these had a momentous impact on drawing palaeogeographic maps.

With time, more papers, text books and conference volumes about plate tectonics and palaeogeography were published, for example, Dewey \& Bird (1970a, b), McKenzie \& Sclater (1971), Tarling \& Runcorn (1972), Hallam (1973a, b), Hughes (1973), Le Pichon, Francheteau \& Bonnin (1973), Marvin (1973), McElhinny (1973), Thenius (1977) and Pomerol (1980), to name a few. We now have not only detailed geographical maps of the entire Earth in the past, down to epoch level (e.g. McKerrow \& Ziegler, 1972; Smith, Briden \& Drewry 1973; Scotese, 1976, 2001, 2004, 2016; Ziegler et al. 1979; Smith, Hurley \& Briden 1981; Wang, 1985; Ronov, Khain \& Balukhovsky, 1989; McKerrow \& Scotese, 1990; Golonka, 2000; Stampfli \& Borel, 2002; Blakey, 2008; Torsvik et al. 2010; Stampfli et al. 
2013; Matthews et al. 2016; Scotese \& Schettino, 2017; Torsvik \& Cocks, 2017), but also regional palaeogeographical maps (e.g. Ziegler, 1982, 1988; Cope, Ingham \& Rawson 1992; Şengör et al. 1988; Şengör \& Natal'in, 1996a; Dercourt et al. 2000; Feng, 2016), some of which show relatively small geographical areas characterized by individual rock types produced by local geological processes (e.g. de Vita \& Martin, 2017). The large amount of knowledge gained in the last decades - especially from the mid-1970s onwards when the geoscientific community generally accepted the plate tectonic theory - is expressed by the increased number of publications related to palaeogeographic research (Fig. 1).

As already said, the results of palaeogeographic analysis are presented in palaeogeographic maps. These maps may however need correction to reverse the deformations that may have affected their area subsequent to the time they are intended to illustrate. This reversal operation is called palinspastic restoration. The term 'palinspastic' comes from the ancient Greek $\pi \alpha \lambda_{\lambda} \imath v$ (palin) meaning ‘back again’ and $\sigma \pi \alpha \sigma \tau \imath \kappa o ́ \varsigma$ (spastikos) meaning 'drawing, pulling'. Palinspastic restoration is particularly crucial in drawing the palaeogeographic maps of areas subsequently subjected to mountain building, during which an area may be shortened by hundreds or even a few thousand kilometres, for example, in the western Himalayan region by c. $1050 \mathrm{~km}$ since c. $50 \mathrm{Ma}$ (e.g. van Hinsbergen et al. 2011). Similarly, areas that are substantially stretched, such as the Basin and Range region in the western United States where ENE-orientated extension may have exceeded $235 \mathrm{~km}$ (McQuarrie \& Wernicke, 2005, p. 167), or areas affected by strike-slip faulting such as the Irtysh and Gornostaev strike-slip systems that moved the Russian craton and the KazakhstanTien Shan domain of the Altaid collage some $2000 \mathrm{~km}$ westwards with respect to the Angaran craton during the late Palaeozoic Era (Şengör \& Natal'in, 1996b, p. 299), need to be palinspastically restored to obtain pre-deformation geographies.

In general, palaeogeographic research has taken enormous steps forward in the past decades. New software tools such as BugPlates (Torsvik, 2009) and GPlates (Williams et al. 2012) allow the development of palaeogeographic animations through geological time (Fig. 19a) and even absolute plate velocities to be considered (Fig. 19b). Reconstructions can easily be corrected if new data are available. Reconstructions of the palaeogeography of an area are usually limited to only two dimensions, however. A promising step forwards is the attempt to incorporate palaeoelevation models representing the palaeotopography and 
drainage systems (Fig. 19c) and palaeobathymetry (Fig. 19d) of the Earth's surface (i.e. adding a third dimension). This provides the boundary conditions for coupled atmosphereocean experiments, for example, and hence for testing palaeoclimate models among others (e.g. Markwick \& Valdes, 2004; Vérard et al. 2015; Baatsen et al. 2016). Seismic tomographic studies are now enabling us to see the tectonic evolution well into the mantle, testing the surface models (e.g. Shephard et al. 2017). Further research in this direction will certainly make an important contribution to an improved understanding of Earth's history.

As we work on new palaeogeographic maps, we should be reminded of something that was said over a century ago: 'When the science of Stratigraphy has developed so that its basis is no longer purely or chiefly palæontological, and when the sciences of Lithogenesis [Petrology], of Orogenesis [Tectonics] and of Glyptogenesis [Geomorphology], as well as of Biogenesis [Evolution], are given their due share in the comprehensive investigation of the history of our earth, then we may hope that Palæogeography, the youthful daughter science of Stratigraphy, will have attained unto that stature which will make it the crowning attraction to the student of earth history' (Grabau, 1913, p. 1147).

\section{Summary}

Palaeogeography maps Earth's ancient environments from the deepest sea to the highest mountains. It is a well-established discipline of the Earth sciences and arose step-bystep, building upon biostratigraphy and lithology, and finally acquired its present modern form by means of the theory of continental drift which was later replaced by plate tectonics. Palaeogeography remains a powerful tool in understanding not only the history of the Earth, but also the processes that have shaped it and continue to shape it. It must be pointed out, however, that there is a give-and-take between the empirical foundations of palaeogeographical research and the theoretical foundations of our understanding of geological processes. Like every geological map, every palaeogeographical map is a hypothesis which represents the geologist's interpretation of the data at hand. Not only are these data hypothesis-laden, but also their interpretation in terms of past geographies is governed by hypotheses linking rock packages to the processes that formed them. As more data accumulate their hypothetical components shrink, and the more we know about the processes the more confidently we can tie rocks to past geographical environments, making 
our palaeogeographical maps better. Better palaeogeographical maps in turn allow us to test more rigorously our hypotheses about geological processes, both now and in the past.

Acknowledgements. We thank W. Gary Ernst and Christopher R. Scotese for their supportive reviews.

\section{References}

AMPFERER, O. 1925. Über Kontinentverschiebungen. Naturwissenschaften 13, 669-75.

AMPFERER, O. 1941. Gedanken über das Bewegungsbild des atlantischen Raumes. Sitzungsberichte der Akademie der Wissenschaften Wien, mathematisch-naturwissenschaftliche Klasse 150, 19-35.

ANDRÉE, K. 1917. Alfred Wegeners Hypothese von der Horizontalverschiebung der Kontinentalschollen und das Permanenzproblem im Lichte der Paläogeographie und dynamischen Geologie. Petermanns Geographische Mitteilungen 63, 50-3 and 77-81.

ARGAND, E. 1924. La tectonique de l'Asie. Extrait du Compte-rendu du XIIle Congrès Géologique International 1922 (Liége: Imprimerie Vaillant-Carmanne) 1, 171-372.

ARLDT, T. 1907. Die Entwicklung der Kontinente und ihrer Lebewelt. Ein Beitrag zur vergleichenden Erdgeschichte. Berlin: Gebrüder Borntraeger, XVII+[I]+729 pp.

ARLDT, T. 1912. Paläogeographische Fragen. Geologische Rundschau 3, 93-111.

ARLDT, T. 1914. Zur Geschichte der paläogeographischen Rekonstruktionen. Geographische Zeitschrift 20, 197-208.

ARLDT, T. 1917-1922. Handbuch der Palaeogeographie. Volume I (Palaeaktologie) and Volume II (Palaeogeographie), Leipzig: Gebrüder Borntraeger, 1647 pp.

ARLDT, T. 1938. Die Entwicklung der Kontinente und ihrer Lebewelt. Ein Beitrag zur vergleichenden Erdgeschichte, 2nd edition. Berlin: Gebrüder Borntraeger, XVIII+1005 pp.

Batitsen, M., van Hinsbergen, D. J. J., von der Heydt, A. S., Dijkstra, H. A., Sluijs, A., Abels, H. A. \& Bijl, P. K. 2016. Reconstructing geographical boundary conditions for palaeoclimate modelling during the Cenozoic. Climate of the Past 12, 1635-44.

BAKER, V. R. 1998. Catastrophism and uniformitarianism: logical roots and current relevance in geology. In Lyell: The Past is the Key to the Present (eds D. J. Blundell \& A. C. Scott), pp. 171-82. Geological Society of London, Special Publication no. 143.

BEUDANT, F.-S. 1841. Cours élémentaire d'histoire naturelle. Géologie. In Cours élémentaire d'histoire naturelle. A l'usage des colléges et des maisons d'education, rédigé conformément au 
programme de l'Université du 14 septembre 1840 (eds F.-S. Beudant, H. Milne-Edwards \& A. de Jussieu), pp. 1-320. Paris: Langlois et Leclercq, and Paris: Fortin, Masson et Cie.

BeUerLEN, K. 1968. Die Problematik paläogeographischer Rekonstruktion. Geologische Rundschau 58, 713-34.

BIRD, J. M. \& DEWEY, J. F. 1970. Lithosphere plate-continental margin tectonics and the evolution of the Appalachian Orogen. Geological Society of America Bulletin 81, 1031-60.

BLAKEY, R. 2008. Gondwana paleogeography from assembly to breakup - a 500 m.y. odyssey. In Resolving the Late Paleozoic Ice Age in Time and Space (eds C. Fielding, T. Frank \& J. Isbell), pp. 1-28. Geological Society of America, Special Paper no. 441.

BouÉ, A. 1875. Einiges zur palaeo-geologischen Geographie. Sitzungsberichte der Kaiserlichen Akademie der Wissenschaften, mathematisch-naturwissenschaftlichen Classe 71, 305-425.

BRADLEY, D. C. 2011. Secular trends in the geologic record and the supercontinental cycle. EarthScience Reviews 108, 16-33.

BroAd, W. J. 1997. The Universe Below: Discovering the Secrets of the Deep Sea. New York: Simon \& Schuster, $432 \mathrm{pp}$.

BUCKLAND, W. 1823. Reliquiae Diluvianae; or, Observations on the Organic Remains Contained in Caves, Fissures, and Diluvial Gravel, and on other Geological Phenomena, Attesting the Action of an Universal Deluge. London: John Murray, 303 pp.

BULLARD, E. 1969. The origin of the oceans. Scientific American 221, 3, 66-75.

BULLARD, E. 1975. The emergence of plate tectonics: a personal view. Annual Review of Earth and Planetary Sciences 3, 1-30.

Bullard, E., EVERETt, J. E. \& SMith A. G. 1965. The fit of the continents around the Atlantic. Philosophical Transactions of the Royal Society of London, Series A, Mathematical and Physical Sciences 258, 41-51.

BURKE, K. \& DEWEY, J. F. 1973. Plume-generated triple junctions. EOS Transactions American Geophysical Union 54, 239.

BURKE, K., DEWEY, J. F. \& KIDD, W. S. F. 1976. Dominance of horizontal movements, arc and microcontinental collisions during the later permobile regime. In The Early History of the Earth (ed. B. F. Windley), pp. 113-29. London and New York: John Wiley \& Sons.

Cande, S. C., Labrecque, J. L., Larson, R. L., Pittman, W. C. III, Golovchenko, X. \& Haxby, W. F. 1989. Magnetic Lineations of the World's Ocean Basins. Tulsa, Oklahoma: American Association of Petroleum Geologists. 
CANU, F. 1895. Essai de paléogéographie. Restauration des contours des Mers anciennes en France et dans les pays voisins. Paris: Imprimerie A. Verger \& E. Baret, 69 pp.

CAREY, S. W. 1955. The orocline concept in geotectonics. Proceedings of the Royal Society of Tasmania 89, 255-88.

CAREY, S. W. 1958. A tectonic approach to continental drift. In Continental Drift: A Symposium (ed. S. W. Carey), pp. 177-355. Hobart: University of Tasmania Press.

CAROzZI, A. 1969. A propos de l'origine de la théorie des dérives continentales: Francis Bacon (1620), François Placet (1668), A. von Humboldt (1801) et A. Snider (1858). Compte rendu des séances de la Société de physique et d'histoire naturelle de Genève, nouvelle série 4, 171-9.

CAROzZI, A. 1970. New historical data on the origin of the theory of continental drift. Geological Society of America Bulletin 81, 283-86.

CAWOOD, P. A., KRÖNER, A. \& PISAREVSKY, S. 2006. Precambrian plate tectonics: Criteria and evidence. GSA Today 16, 7, 4-11.

CHOUBERT, B. 1935. Recherches sur la genèse des chaînes paléozoîques et antécambriennes. Revue de Géographie Physique et de Géologie Dynamique 8, 5-50.

CHOUBeRT, B. 1981. Aperçu de l'évolution des idées concernant la formation de la croûte terrestre d'Alfred Wegener à nos jours. Geologische Rundschau 70, 40-9.

CONDIE, K. C. 2016. A planet in transition: The onset of plate tectonics on Earth between 3 and 2 Ga? Geoscience Frontiers, published online 22 September 2016, doi: 10.1016/j.gsf.2016.09.001.

Condie, K. C. \& PeASE, V. (eds) 2008. When Did Plate Tectonics Begin on Planet Earth? Geological Society of America, Special Paper no. 440, 294 pp.

COPE, J. C. W., INGHAM, J. K. \& RAWSON, P. F. (eds) 1992. Atlas of Palaogeography and Lithofacies. Geological Society of London, Memoir no. 13, $153 \mathrm{pp}$.

Cox, A. 1973. Plate Tectonics and Geomagnetic Reversals. San Francisco: W. H. Freeman \& Co. Ltd, $702 \mathrm{pp}$.

COX, A. \& HART, R. B. 1986. Plate Tectonics: How it Works. Oxford: Wiley-Blackwell, 382 pp.

CREER, K. M. \& IRVING, E. 2012. Testing continental drift: constructing the first palaeomagnetic path of polar wander (1954). Earth Sciences History 31, 111-45.

CUVIER, G. 1825. Discours sur les révolutions de la surface du globe et sur les changements qu'elles ont produits dans le règne animal. Paris: G. Dufour et Éd. d'Ocagne, 400 pp.

DACQUÉ, E. 1913. Paläogeographische Karten und die gegen sie zu erhebenden Einwände. Geologische Rundschau 4, 186-206.

DACQUÉ, E. 1915. Grundlagen und Methoden der Paläogeographie. Jena: Gustav Fischer, 526 pp. 
DACQUÉ, E. 1919. Geographie der Vorwelt (Paläogeographie). Leipzig: B. G. Teubner, 104 pp.

DACQUÉ, E. 1926. Paläogeographie. Leipzig und Wien: Franz Deuticke, VIII+196 pp.

DALY, R. A. 1926. Our Mobile Earth. New York: Charles Scribner's Sons, 342 pp.

DANA, J. D. 1863. Manual of Geology: Treating of the Principles of the Science with Special Reference to American Geological History, for the use of Colleges, Academies and Schools of Science. Philadelphia: Theodore Bliss, 798 pp.

DARWIN, C. 1859. On the Origin of Species by means of Natural Selection, or the Preservation of Favoured Races in the Struggle for Life. London: John Murray, 502 pp.

DAVIES, G. L. 1965. Francis Bacon and continental drift. Geological Magazine 102, 347.

DAVIES, G. F. 1992. On the emergence of plate tectonics. Geology 20, 963-6.

DE BEAUMONT, E. L. 1833. Observations sur l'étendue du système tertiaire inférieur dans le nord de la France et sur les dépôts de lignite quis'y trouvent. Mémoires de la Société Géologique de France, 1ère série, tome l, mémoire 5, 15 pp.

DE LAMANON, J. H. DE R. 1782. De divers fossiles trouvés dans les carrières de Montmartre près Paris, et vues générales sur la formation des pierres gypseuses. Observations et mémoires sur la physique, sur l'histoire naturelle, et sur les arts et métiers 19, 173-94.

DE LAPPARENT, A. 1900. Traité de Géologie, 4th edition. Paris: Masson et Cie.

Dercourt, J., Gaetani, M., Vrielynck, B., Barrier, E., Biju-Duval, B., Brunet, M. F., Cadet, J. P., Crasquin, S. \& SAndulescu, M. 2000. Atlas Peri-Tethys, Palaogeographical Maps. Paris: Commision de la Carte Géologique du Monde, 1137 pp.

DE SAUSSURE, H. B. 1779. Voyages dans les Alpes, précédés d'un essai sur l'histoire naturelle des environs de Geneve. Neuchatel: Tome Premier, Chez Samuel Fauche, 540 pp.

DE VITA, S. \& MARTIN, F. F. 2017. The palaeogeographic setting and the local environmental impact of the 130 ka Falconiera tuff-cone eruption (Ustica island, Italy). Annals of Geophysics 60(2), S0224, doi: 10.4401/ag-7113.

DEWEY, J. F. 1969a. The evolution of the Appalachian/Caledonian orogen. Nature 222, 124-9.

DEWEY, J. F. 1969b. Continental margins: A model for conversion of Atlantic type to Andean type. Earth and Planetary Science Letters 6, 189-97.

DEWEY, J. F. 1975. Finite plate implications: some implications for the evolution of rock masses at plate margins. American Journal of Science 275-A, 260-84. 
DEWEY, J. F. 1988. Lithospheric stress, deformation, and tectonic cycles: the disruption of Pangaea and the closure of Tethys. In Gondwana and Tethys (eds M. G. Aufley-Charles \& A. Hallam), pp. 23-40. Geological Society of London, Special Publication no. 37.

DEWEY, J. F. 2015. A harbinger of plate tectonics: a commentary on Bullard, Everett and Smith (1965) 'The fit of the continents around the Atlantic'. Philosophical Transactions of the Royal Society A: Mathematical, Physical \& Engineering Sciences 373, 20140227, doi: 10.1098/rsta.2014.0227.

DEWEY, J. \& BIRD, J. 1970a. Plate tectonics and geosynclines. Tectonophysics 10, 625-38.

DEWEY, J. F. \& BIRD, J. M. 1970b. Mountain belts and the new global tectonics. Journal of Geophysical Research 75, 2625-47.

DEWEY, J. F. \& BIRD, J. M. 1971. Origin and emplacement of the ophiolite suite: Appalachian ophiolites in Newfoundland. Journal of Geophysical Research 76, 3179-206.

DE WIT, M. \& AshWAL, L. D. (eds) 1997. Greenstone Belts. Oxford: Clarendon Press, 809 pp. Oxford Monographs on Geology and Geophysics no. 35.

DICKINSON, W. R. 1971a. Plate tectonic models for orogeny at continental margins. Nature 232, 41-2.

DICKINSON, W. R. 1971b. Plate tectonics in geologic history. Science 174, 107-13.

DIETZ, R. S. 1961. Continent and ocean basin evolution by spreading of the sea floor. Nature 190, 854-7.

DU TOIT, A. L. 1927. A Geological Comparison of South America with South Africa. Publication of the Carnegie Institution of Washington 381, 1-158.

DU TOIT, A. L. 1937. Our Wandering Continents: An Hypothesis of Continental Drifting. London: Oliver and Boyd, 366 pp.

DU ToIT, A. L. 1952. Comparação Geológica entre a América do Sul e a África do Sul. Serviço Gråfico do Instituto Brasileiro de Geografia e Estatística, Rio de Janeiro, XII+179 pp., 11 plates, 1 foldout map.

ERNST, W. G. 2017. Kimberlites and the start of plate tectonics: Comment. Geology 45, 1, e405.

ERNST, W. G., SLEEP, N. H. \& TSUIIMORI, T. 2016. Plate-tectonic evolution of the Earth: bottom-up and top-down mantle circulation. Canadian Journal of Earth Sciences 53, 1103-20.

ETHERIDGE, R. 1881. Anniversary address of the president: On the analysis and distribution of the British Palaeozoic fossils. Quarterly Journal of the Geological Society, London 37, 37-235.

FENG, Z. Z. 2016. On palaeogeographic map. Journal of Palaeogeography 5, 1-27. 
FORBES, E. 1846. On the connection between the distribution of the existing fauna and flora of the British Isles, and the geological changes which have affected their area, especially during the epoch of the northern drift. Great Britain Geological Survey, Memoir 1, 336-432.

FORSYTH, D. \& UYEDA, S. 1975. On the relative importance of the driving forces of plate motion. Geophysical Journal of the Royal Astronomical Society 43, 163-200.

FreShFieLD, D. W. 1920. The life of Horace Bénédict de Saussure. London: Edward Arnold, 479 pp.

GolonkA, J. 2000. Cambrian-Neogene Plate Tectonic Maps. Kraków: Wydawnictwa Uniwersytetu Jagielloñskiego, 125 pp.

GrabaU, A. W. 1909. Physical and faunal evolution of North America during the Ordovicic, Siluric, and Early Devonic time. Journal of Geology 17, 209-52.

GrabaU, A. W. 1912. Über die Einteilung des nordamerikanischen Silurs. Compte rendu de la Xle session du Congrès géologique international (Stockholm 1910). Deuxième Fascicule, pp. 979-95. Stockholm: Kungl. Boktryckeriet P. A. Norstedt \& Söner.

Grabau, A. W. 1913. Principles of Stratigraphy. New York: A. G. Seiler and Company, 1185 pp.

HABER, F. 1927. Das Gold im Meerwasser. Zeitschrift für Angewandte Chemie 40, 303-17.

HALLAM, A. (ed.) 1973a. Atlas of Palaeobiogeography. Amsterdam: Elsevier, 531 pp.

Hallam, A. 1973b. A Revolution in Earth Sciences: From Continental Drift to Plate Tectonics. Oxford: Clarendon Press, 127 pp.

HAMILTON, W. 1969. Mesozoic California and the underflow of Pacific mantle. Geological Society of America Bulletin 80, 2409-30.

HAMILTON, W. 1970. The Uralides and the motion of the Russian and Siberian platforms. Geological Society of America Bulletin 81, 2553-76.

harrison, M. T., Blichert-Toft, J., Müller, W., Albarede, F., Holden, P. \& Mojzsis, S. J. 2005. Heterogeneous Hadean hafnium: evidence of continental crust at 4.4 to $4.5 \mathrm{Ga}$. Science $\mathbf{3 1 0}$, 1947-50.

HAStie, A. R., Fitton, J. G., Bromiley, G. D., Butler, I. B. \& OdLIng, N. W. A. 2016. The origin of Earth's first continents and the onset of plate tectonics. Geology 44, 855-8.

HeEZEN, B. C. \& TharP, M. 1965. Tectonic fabric of the Atlantic and Indian oceans and continental drift. Philosophical Transactions of the Royal Society of London, Series A: Mathematical and Physical Sciences 258, 90-106.

HeEzen, B. C., Tharp, M. \& EWING, M. (eds) 1959. The Floor of the Oceans. I. The North Atlantic. Geological Society of America, Special Paper no. 65, 122 pp. 
HESS, H. H. 1962. History of ocean basins. In Petrologic Studies: A Volume in Honor of A. F. Buddington (eds A. E. J. Engel, H. L. James \& B. F. Leonard), pp. 599-620. New York: Geological Society of America.

Holmes, A. 1913. The Age of the Earth. London and New York: Harper \& Brothers, 196 pp.

Holmes, A. 1928. Radioactivity and continental drift. Geological Magazine 65, 236-38.

HoLMES, A. 1931. Radioactivity and Earth movements. Transactions of the Geological Society of Glasgow for 1928-29 18, 559-606.

Holmes, A. 1944. Principles of Physical Geology. London, Edinburgh, Paris, Melbourne, Toronto, New York: Thomas Nelson and Sons Ltd., 532 pp.

HOLMES, A. 1946. An estimate of the age of the Earth. Nature 157, 680-4.

HORVITZ, L. A. 2002. Eureka! Scientific Breakthroughs that Changed the World. New York: John Wiley \& Sons, $256 \mathrm{pp}$.

Hughes, N. F. (ed.) 1973. Organisms and continents through time: a symposium. Special Papers in Palaeontology 12. London: Palaeontological Association, 334 pp.

HUNT, T. S. 1873. The Paleogeography of the North-American Continent. Journal of the American Geographical Society of New York 4, 416-31.

HUTTON, J. 1788. Theory of the Earth; or an investigation of the laws observable in the composition, dissolution, and restoration of land upon the Globe. Transactions of the Royal Society of Edinburgh 1/2, 209-304.

IRVING, E. 1977. Drift of the major continental blocks since the Devonian. Nature 270, 304-9.

IRVING, E. 1988. The paleomagnetic confirmation of continental drift. Eos, Transactions American

Geophysical Union 69, 994-1014.

ISACKS, B., OLIVER, J. \& SYKES, L. R. 1968. Seismology and the new global tectonics. Journal of Geophysical Research 73, 5855-99.

JAWORSKI, E. 1922. Die A. Wegener'sche Hypothese der Kontinentalverschiebungen: Eine kritische Zusammenstellung. Geologische Rundschau 13, 273-96.

JoleAud, L. 1939. Atlas de Paléobiogéographie. Paris: Paul Lechevalier, 39 pp. (+99 plates).

Kerner-Marilaun, F. 1934. Paläogeographie mit besonderer Rücksicht auf die Fehlerquellen. Berlin: Gebrüder Borntraeger, 410 pp.

KIOUS, W. J. \& TILLING, R. I. 1996. This Dynamic Earth: The Story of Plate Tectonics. Washington, DC: United States Geological Survey, 56 pp.

KOKEN, E. 1893. Die Vorwelt und ihre Entwicklungsgeschichte. Leipzig: T. O. Weigel, 672 pp. 
KÖPPEN, W. 1940. Die Klimate der geologischen Vorzeit: Ergänzungen und Berichtigungen. Berlin: Gebrüder Borntraeger, 38 pp.

KÖPPEN, W. \& WeGENER, A. 1924. Die Klimate der geologischen Vorzeit. Berlin: Gebrüder Borntraeger, 255 pp.

KÖPPEN, W. \& Wegener, A. 2015. The Climates of the Geological Past/Die Klimate der geologischen Vorzeit. Reproduction of the original 1924 German edition and complete English translation (eds J. Thiede, K. Lochte \& A. Dummermuth). Stuttgart: Borntraeger Scientific Publishers, 657 pp.

KORENAGA, J. 2013. Initiation and evolution of plate tectonics on Earth: Theories and observations. Annual Review of Earth and Planetary Sciences 41, 117-51.

KORNPROBST, J. 2017. Boris Choubert: The forgotten fit of the circum-Atlantic continents. Comptes Rendus Geoscience 349, 42-8.

Kossmat, F. 1908. Paläogeographie. Leipzig: De Gruyter Verlag, 136 pp.

KosSMAT, F. 1921. Erörterungen zu A. Wegeners Theorie der Kontinentalverschiebungen. Zeitschrift der Gesellschaft für Erdkunde zu Berlin 1921, 103-10.

KosSmat, F. 1936. Paläogeographie und Tektonik. Berlin: Gebrüder Borntraeger, 413 pp.

LAUBSCHER, H. 1969. Mountain building. Tectonophysics 7, 551-63.

LE PICHON, X. 1968. Sea floor spreading and continental drift. Journal of Geophysical Research 73, 3661-97.

Le Pichon, X., Francheteau, J. \& Bonnin, J. 1973. Plate Tectonics. Amsterdam: Elsevier, 300 pp.

LETSCH, D. 2017. A pioneer of Precambrian geology: Boris Choubert's fit of the continents across the Atlantic (1935) and his insights into the Proterozoic tectonic structure of the West African Craton and adjacent areas. Precambrian Research 294, 230-43.

LEVITON, A. \& ALDRICH, M. 2012. Contributions of the Geological Survey of India, 1851-1890, to the concept of Gondwána-Land. Earth Sciences History 31, 247-69.

LeVorSEN, A. I. 1960. Paleogeologic Maps. San Francisco and London: W. H. Freeman and Co., 174 pp.

LILIENTHAL, T. C. 1756. Die gute Sache der in der heiligen Schrift alten und neuen Testaments enthaltenen Göttlichen Offenbarung, wider die Feinde derselben erwiesen und gerettet. Volume 7. Königsberg: Johann Heinrich Hartung, 588 pp.

LYELL, C. 1830-1833. Principles of Geology, being an Attempt to Explain the Former Changes of the Earth's Surface, by Reference to causes now in Operation. Volumes 1-3. London: John Murray. 
LYELL, C. 1835. Principles of Geology, being an Attempt to Explain the Former Changes of the Earth's Surface, by Reference to causes now in Operation, 4th edition, Volume 1. London: John Murray.

LYELL, C. 1839. Nouveaux éléments de géologie. Paris: Pitois-Levrault, 648 pp.

MARCOU, J. 1857-1860. Lettres sur les roches du Jura et leur distribution géographique dans les deux hémisphères. Paris: Friedrich Klincksieck, 364 pp.

MARKWICK, P. J. \& VALDES, P. J. 2004. Palaeo-digital elevation models for use as boundary conditions in coupled ocean-atmosphere GCM experiments: a Maastrichtian (late Cretaceous) example. Palaeogeography, Palaeoclimatology, Palaeoecology 213, 37-63.

MARVIN, U. B. 1973. Continental Drift. The Evolution of a Concept. Washington, DC: Smithsonian Institute, $239 \mathrm{pp}$.

MASON, R. G. 1958. A magnetic survey off the west coast of the United States between latitudes $32^{\circ}$ and $36^{\circ} \mathrm{N}$, longitudes $121^{\circ}$ and $128^{\circ} \mathrm{W}$. Geophysical Journal of the Royal Astronomical Society 1, 320-9.

MASON, R. G. \& RAFF, A. D. 1961. A magnetic survey off the west coast of North America, $32^{\circ} \mathrm{N}$ to $42^{\circ}$ N. Geological Society of America Bulletin 72, 1259-65.

MATTHEW, W. D. 1906. Hypothetical outlines of the continents in Tertiary times. Bulletin of the American Museum of Natural History 22, 353-83.

Matthews, K. J., Maloney, K. T., Zahirovic, S., Williams, S. E., Seton, M. \& Müller, R. D. 2016. Global plate boundary evolution and kinematics since the late Paleozoic. Global and Planetary Change 146, 226-50.

MAURER, H. \& StOcks, T. 1933. Die Echolotungen des 'Meteor'. Wissenschaftliche Ergebnisse der deutschen atlantischen Expedition auf dem Forschungs- und Vermessungsschiff 'Meteor' 1925-19272, 1-309.

Maury, M. F. 1855. The Physical Geography of the Sea. New York: Harper \& Brothers, 310 pp.

MCElhinnY, M. W. 1973. Palaeomagnetism and Plate Tectonics. Cambridge: Cambridge University Press, 358 pp.

McKenzie, D. \& PARKeR, R. 1967. The North Pacific: An example of tectonics on a sphere. Nature 216, 1276-80.

McKenZie, D. \& Sclater, J. G. 1971. The evolution of the Indian Ocean since the late Cretaceous. Geophysical Journal of Royal Astronomical Society 25, 437-528.

MCKerrow, W. \& SCOteSE, C. R. (eds) 1990. Palaeozoic Palaogeography and Biogeography. Geological Society of London, Memoir no. 12, 435 pp. 
MCKeRROW, W. S. \& ZiegleR, A. M. 1972. Palaeozoic Oceans. Nature 240, 92-4.

MCQUARRIE, N. \& WERNICKE, B. P. 2005. An animated tectonic reconstruction of southwestern North America since 36 Ma. Geosphere 1, 147-72.

Medicott, H. B. \& BlANDFORD, W. T. 1879. A Manual of the Geology of India. 2 volumes. Calcutta: Geological Survey of India.

Mero, J. L. 1965. The Mineral Resources of the Sea. Amsterdam: Elsevier, 312 pp., Elsevier Oceanography Series no. 1.

MitchelL, A. H. \& ReAding, H. G. 1969. Continental margins, geosynclines, and ocean floor spreading. Journal of Geology 77, 629-46.

MolengraAf, G. A. F. 1916. The coral reef problem and isostasy. Proceedings of the Koninklijke Nederlandsche Akademie van Wetenschappen Amsterdam 19, 610-27.

MolengraAF, G. A. F. 1928. Wegener's continental drift. In Theory of Continental Drift: Symposium on the Origin and Movement of Land Masses both Inter-Continental and Intra-Continental, as Proposed by Alfred Wegener (eds W. A. J. M. van Waterschoot van der Gracht, B. Willis, R. T. Chamberlin, J. Joly, G. A. F. Molengraaff, J. W. Gregory, A. Wegener, C. Schuchert, C. R. Longwell, F. B. Taylor, W. Bowie, D. White, J. T. Singewald Jr. \& E. W. Berry), pp. 90-2. American Association of Petroleum Geologists, Special Publication.

MORGAN, J. 1968. Rises, trenches, great faults, and crustal blocks. Journal of Geophysical Research 73, 1959-82.

Müller, R. D., Seton, M., Zahirovic, S., Williams, S. E., MattheWs, K. J., Wright, N. M., Shephard, G. E., Maloney, K. T., BARnett-Moore, N., HosseinPour, M., BoWer, D. J. \& CANnON, J. 2016. Ocean basin evolution and global-scale plate reorganization events since Pangea breakup. Annual Review of Earth and Planetary Sciences 44, 107-38.

MURRAY, J. \& ReNARD, A. F. 1891. Report on the deep-sea deposits based on the specimens collected during the voyage of H.M.S. Challenger in the years 1872 to 1876. Edinburgh: H.M. Stationery Office, $525 \mathrm{pp}$.

NANCE, R. D., MURPHY, J. B. \& SANTOSH, M. 2014. The supercontinent cycle: a retrospective essay. Gondwana Research 25, 4-29.

NeUMAYR, M. 1885. Die geographische Verbreitung der Juraformation. Denkschriften der kaiserlichen Akademie der Wissenschaften in Wien, mathematisch-natwisseenschfatliche Classe 50, 57144. 
NöLKE, F. 1922. Physikalische Bedenken gegen A. Wegeners Hypothese der Entstehung der Kontinente und Ozeane. Petermanns geographische Mitteilungen 68, 114-5.

OpPenHeIM, V. 1967. Critique of hypothesis of continental drift. American Association of Petroleum Geologists Bulletin 51, 1354-67.

ORESKES, N. 1999. The Rejection of Continental Drift: Theory and Method in American Earth Science. New York: Oxford University Press, 432 pp.

ORTELIUS, A. 1570. Typus orbis terrarum. Antwerp: Officina Plantiniana.

OrTELIUS, A. 1596. Thesaurus Geographicus, recognitus et auctus. In quo omnium totius terræ regionum, montium, promontoriorum, collium, siluarum, desertorum, insularum, portuum, populorum, vrbium, opidorum, pagorum, fanorum, tribuum: Item oceani marium, fretorum, fluuiorum, torrentium, sinuum, fontium, lacuum, paludumq́ue nomina \& apellationes veteres; additis magna ex parte etiam recentioribus. Antwerp: Officina Plantiniana.

Osborne, C. P., Royer, D. L. \& BeERLING, D. J. 2004. Adaptive role of leaf habit in extinct polar forests. International Forestry Review 6, 181-6.

OWEN, R. 1857. Key to the Geology of the Globe: An Essay, Designed to show that the Present Geographical, Hydrographical, and Geological Structures, Observed on the Earth's Crust, were the Result of Forces Acting According to Fixed, Demonstrable Laws, Analogous to those Governing the Development of Organic Bodies. Boston: Gould and Lincoln, 256 pp.

PENCK, A. 1921. Wegeners Hypothese der kontinentalen Verschiebungen. Zeitschrift der Gesellschaft für Erdkunde zu Berlin 1921, 110-20.

PITMAN, W. C. III \& HeIRTZLER, J. R. 1966. Magnetic anomalies over the Pacific-Antarctic Ridge. Science 154, 1164-71.

PLAYFAIR, J. 1802. Illustrations of the Huttonian Theory of the Earth. London: Cadell and Davies. Edinburgh: William Creech, 528 pp.

PolAt, A., KERRICH, R. \& WINDLEY, B. 2009. Archaean crustal growth processes in southern West Greenland and the southern Superior Province: geodynamic and magmatic constraints. In Earth Accretionary Systems in Space and Time (eds P. Cawood \& A. Kröner), pp. 155-91. Geological Society of London, Special Publication no. 318.

Pomerol, C. 1980. Stratigraphie et Paléogéographie: Principes et Méthodes. Paris: Doin, 209 pp. RoMM, J. 1994. A new forerunner for continental drift. Nature 367, 407-8.

Ronov, A., KHAIN, V. \& BALUKHovsky, A. 1989. Atlas of Lithological-Paleogeographical Maps of the World: Mesozoic and Cenozoic of Continents and Oceans. Leningrad: USSR Academy of Sciences, $79 \mathrm{pp}$. 
SCHUCHERT, C. 1910. Palaeogeography of North America. Geological Society of America Bulletin 20, 427-606.

SCHUCHERT, C. 1911. Palaeogeographic and geologic significance of recent brachiopoda. Geological Society of America Bulletin 22, 258-75.

SCHUCHERT, C. 1955. Atlas of Palaeogeographic Maps of North America. New York: Wiley, 177 pp.

SCHWEYDAR, W. 1921. Bemerkungen zu Wegeners Hypothese der Verschiebung der Kontinente. Zeitschrift der Gesellschaft für Erdkunde zu Berlin 1921, 120-5.

SCHWINNER, R. 1920. Vulkanismus und Gebirgsbildung. Ein Versuch. Zeitschrift für Vulkanologie 5, $175-230$.

SCHWINNER, R. 1941. Der Begriff der Konvektionsströmung in der Mechanik der Erde. Gerlands Beiträge zur Geophysik 58, 119-58.

SCOTESE, C. R. 1976. A continental drift 'flip book'. Computers \& Geosciences 2, 113-6.

SCOTESE, C. R. 2001. Atlas of Earth History. Volume 1, Paleogeography. Arlington, Texas: PALEOMAP Project, $52 \mathrm{pp}$.

SCOTESE, C. R. 2004. A continental drift flipbook. Journal of Geology 112, 729-41.

SCOTESE, C. R. 2016. Tutorial: PALEOMAP PaleoAtlas for GPlates and the PaleoData Plotter Program. Available at http://www.earthbyte.org/paleomap-paleoatlas-for-gplates/ (accessed 5 December 2017).

SCOTESE, C. R. \& SCHETtINO, A. 2017. Chapter 3: Late Permian-Early Jurassic Paleogeography of Western Tethys and the World. In Permo-Triassic Salt Provinces of Europe, North Africa and the Atlantic Margins (eds J. I. Soto, J. Flinch \& G. Tari), pp. 57-95. Amsterdam: Elsevier.

SCUPIN, H. 1940. Palaeogeographie: Grundfragen und Forschung. Stuttgart: Schweizerbart, 164 pp.

ŞENGÖR, A. M. C. 2001. Is the Present the Key to the Past or the Past the Key to the Present? James Hutton and Adam Smith versus Abraham Gottlob Werner and Karl Marx in Interpreting History. Geological Society of America, Special Paper no. 355, x+51 pp. [AQ1]

ŞENGÖR, A. M. C. 2003. The large-wavelength deformations of the lithosphere: Materials for a history of the evolution of thought from the earliest times to plate tectonics. Geological Society of America Memoir 196, xvii+347 pp. [AQ2]

ŞENGÖR, A. M. C. 2014a. Eduard Suess and global tectonics: an illustrated 'short guide': Austrian Journal of Earth Sciences (Suess special issue) 107, 6-82.

ŞENGÖR, A. M. C. 2014b. Pangäische Spiele 2012. Mitteilungen des naturwissenschaftlichen Vereins für Steiermark 143, 7-48. 
ŞENGÖR, A. M. C. 2015. The founder of modern geology died 100 years ago: the scientific work and legacy of Eduard Suess. Geoscience Canada 42, 181-246.

Şengör, A. M. C., Altiner, D., CIN, A., UStAöMeR, T. \& Hsü, K. J. 1988. Origin and assembly of the Tethyside orogenic collage at the expense of Gondwana-Land. In Gondwana and Tethys (eds M. G. Aufley-Charles \& A. Hallam), pp. 119-81. Geological Society of London, Special Publication no. 37.

ŞENGÖR, A. M. C. \& NATAL'IN, B. A. 1996a. Palaeotectonics of Asia: Fragments of A Synthesis. In The Tectonic Evolution of Asia (A. Yin \& M. Harrison), pp. 486-40. Cambridge: Cambridge University Press.

ŞENGÖR, A. M. C. \& NATAL'IN, B. A. 1996b. Turkic-Type orogeny and its role in the making of the continental crust. Annual Review of Earth and Planetary Sciences 24, 263-338.

Shephard, G. E., MATtheWS, K. J., HosseinI K. \& Domeier M. 2017. On the consistency of seismically imaged lower mantle slabs. Scientific Reports 7, 10976, doi: 10.1038/s41598-017-11039-w.

SMITH, A. G., BRIDEN, J. C. \& DREWRY, G. E. 1973. Phanerozoic world maps. In Organisms and Continents Through Time (ed. N. F. Hughes), pp. 1-42. Special Papers in Palaeontology no. 12. London: The Palaeontological Association [AQ3]

SMITH, A. G. \& HALLAM, A. 1970. The fit of the southern continents. Nature 225, 139-44.

SMith, A. G., HuRley, A. M. \& Briden, J. C. 1981. Phanerozoic Palaeocontinental World Maps. Cambridge: Cambridge University Press, 102 pp.

SNIDER, A. 1859. La Création et ses mystères dévoilés. Paris: A. Franck and E. Dentu, 487 pp.

SoERGEL, W. 1916. Die atlantische "Spalte". Kritische Bemerkungen zu A. Wegeners Theorie von der Kontinentalverschiebung. Zeitschrift der Deutschen Geologischen Gesellschaft 68, 200-39.

StAMPfLI, G. M. \& BoreL, G. D. 2002. A plate tectonic model for the Paleozoic and Mesozoic constrained by dynamic plate boundaries and restored synthetic oceanic isochrones. Earth and Planetary Science Letters 196, 17-33.

Stampfli, G. M., Hochard, C., Vérard, C., Wilhem, C. \& von RAumer, J. 2013. The formation of Pangea. Tectonophysics 593, 1-19.

STERN, R. J. 2005. Evidence from ophiolites, blueschists, and ultrahigh-pressure metamorphic terranes that the modern episode of subduction tectonics began in Neoproterozoic time. Geology 33, 557-60.

Stern, R. J., LeYbourne, M. I. \& TSUJIMORI, T. 2016. Kimberlites and the start of plate tectonics. Geology 44, 799-802. 
Stern, R. J., Leybourne, M. I. \& TSUJIMORI, T. 2017. Kimberlites and the start of plate tectonics: Reply. Geology 45, 1, e406.

Stocks, T. \& WüST, G. 1935. Die Tiefenverhältnisse des offenen Atlantischen Ozeans. Wissenschaftliche Ergebnisse der Deutschen Atlantischen Expedition auf dem Forschungsund Vermessungsschiff 'Meteor' 1925-1927 3, 1-31.

SUESS, E. 1883. Das Antlitz der Erde. Volume la. Prag-Wien: F. Tempsky and Leipzig: G. Freytag, 310 pp.

SuESS, E. 1885. Das Antlitz der Erde. Volume Ib. Prag-Wien: F. Tempsky and Leipzig: G. Freytag, pp. $311-778$.

SuESS, E. 1888. Das Antlitz der Erde. Volume II. Prag-Wien: F. Tempsky and Leipzig: G. Freytag, 703 pp.

SUESS, E. 1893. Are great ocean depths permanent? Natural Science 2, 180-7.

SuESS, E. 1901. Das Antlitz der Erde. Volume III/1 (Dritter Band. Erste Hälfte). Prag-Wien: F. Tempsky and Leipzig: G. Freytag, 508 pp.

SuESS, E. 1909. Das Antlitz der Erde. Volume III/2 (Dritter Band. Zweite Hälfte. Schluss des Gesamtwerkes). Prag-Wien: F. Tempsky and Leipzig: G. Freytag, 789 pp.

SYKES, L. R. 1967. Mechanism of earthquakes and nature of faulting on the mid-oceanic ridges. Journal of Geophysical Research 72, 2131-53.

TARLING, D. H. \& RUNCORN, S. K. (eds) 1973. Implications of Continental Drift to the Earth Sciences. Volumes 1 and 2. London, New York: Academic Press, 1184 pp.

Termier, H. \& Termier, G. 1960. Atlas de Paléogéographie. Paris: Masson \& Cie, 99 pp.

THENIUS, E. 1977. Meere und Länder im Wechsel der Zeiten: Die Paläogeographie als Grundlage für die Biogeographie. Berlin, Heidelberg, New York: Springer, 216 pp.

THENIUS, E. 1988. Otto Ampferer, Begründer der Theorie der Ozeanbodenspreizung. Die Geowissenschaften 6, 4, 103-5.

TORSVIK, T. H. 2009. BugPlates: Linking Biogeography and Palaeogeography. Trondheim/Norway: Centre for Geodynamics.

TORSVIK, T. H. \& COCKS, L. R. M. 2017. Earth History and Palaeogeography. Cambridge: Cambridge University Press, 317 pp.

Torsvik, T. H., Steinberger, B., Gurnis, M. \& GainA, C. 2010. Plate tectonics and net lithosphere rotation over the past 150 My. Earth and Planetary Science Letters 291, 106-12.

TOULA, F. 1908. Das Wandern und Schwanken der Meere. Schriften des Vereines zur Verbreitung naturwissenschaftlicher Kenntnisse in Wien 48, 291-349. 
VAN DER VOO, R. 1993. Paleomagnetism of the Atlantic, Tethys and lapetus Oceans. Cambridge: Cambridge University Press, 411 pp.

VAN DER VOO, R. \& FRENCH, R. B. 1974. Apparent polar wandering for the Atlantic-bordering continents: Late Carboniferous to Eocene. Earth-Science Reviews 10, 99-119.

VAn Hinsbergen, D. J. J., Kapp, P., Dupont-Nivet, G., Lippert, P. C., DeCelles, P. G. \& Torsvik, T. H. 2011. Restoration of Cenozoic deformation in Asia, and the size of Greater India. Tectonics 30, TC5003, doi:10.1029/2011TC002908.

VAN HOUTEN, F. B. 1975. A precocious Atlantic reconstruction: an historical note. Geology 3(4), 194-5.

VARENIUS, B. 1650. Geographia Generalis, in qua Affectiones Generales Telluris Explicantur. Amstelodami: Apud Ludovicum Elzevirium, 786 pp.

VÉrard, C., Hochard, C., Baumgartner, P. O. \& StAMPfl, G. M. 2015. 3D palaeogeographic reconstructions of the Phanerozoic versus sea-level and Sr-ratio variations. Journal of Palaeogeography 4, 64-84.

VINE, F. J. \& MATTHEWS, D. H. 1963. Magnetic anomalies over ocean ridges. Nature 199, 947-9. VON HUMBOLDT, A. 1801. Alexander von Humboldt's neue physikalische Beobachtungen im spanischen Amerika. Annalen der Physik 7, 329-47.

von HUMBoldt, A. 1804. Geognostische Skizze von Südamerika. Annalen der Physik 16, 394-449. VON HUMBoLdT, A. 1845a. Kosmos: A General Survey of Physical Phenomena of the Universe. Volume 1. London: Hippolyte Baillière, 482 pp.

VON HUMBOLDT, A. 1845b. Kosmos: Entwurf einer physischen Weltbeschreibung. Volume 1. Stuttgart and Tübingen: J. G. Cotta'scher Verlag, 493 pp.

WANG, H. 1985. Atlas of the Palaeogeography of China. Beijing: Cartographic Publishing House, 143 pp. [maps and cross sections], 85 pp. [in Chinese], 28 pp. [in English].

Wegener, A. 1912a. Die Entstehung der Kontinente. Geologische Rundschau 3, 276-92.

WeGener, A. 1912b. Die Entstehung der Kontinente. Petermanns Geographische Mitteilungen 58, 185-95, 253-6, 305-9.

WeGENER, A. 1915. Die Entstehung der Kontinente und Ozeane, 1st edition. Braunschweig: Friedrich Vieweg \& Sohn, 94 pp.

WEGENER, A. 1920. Die Entstehung der Kontinente und Ozeane, 2nd edition. Braunschweig: Friedrich Vieweg \& Sohn, 135 pp.

WEGENER, A. 1922. Die Entstehung der Kontinente und Ozeane, 3rd edition. Braunschweig: Friedrich Vieweg \& Sohn, 144 pp. 
WEGENER, A. 1929. Die Entstehung der Kontinente und Ozeane, 4th edition. Braunschweig: Friedrich Vieweg \& Sohn, $231 \mathrm{pp}$.

WEGENER, A. 1966. The Origin of Continents and Oceans. Translated by John Biram from the Fourth (1929) revised German edition. New York: Dover Publications Inc., 246 pp.

Williams, S., Müller, R. D., LANDgrebe, T. C. W. \& WhitTAKeR, J. M. 2012. An open-source software environment for visualizing and refining plate tectonic reconstructions using high resolution geological and geophysical data sets. GSA Today 22(4), 4-9.

WILLIS, B. 1909. Paleogeographic maps of North America. Journal of Geology 17, 203-8, 253-6, 2868, 342-3, 403-9, 424-8, 503-8, 600-2.

WILLIS, B. 1910. Principles of Paleogeography. Science 31, 241-60.

WILLIS, B. 1944. Continental drift, ein Märchen. American Journal of Science 242, 509-13.

WILLS, L. J. 1951. A Palaeogeographical Atlas of the British Isles and Adjacent Parts of Europe. London: Blackie \& Son Ltd., 64 pp.

WILSON, J. T. 1963. A possible origin of the Hawaiian Islands. Canadian Journal of Physics 41, 863-70.

WILSON, J. T. 1965. A new class of faults and their bearing on continental drift. Nature 207, 343-7.

WILSON, J. T. 1966. Did the Atlantic close and then re-open? Nature 211, 676-81.

WILSON, J. T. (ed.) 1972. Continents adrift: Readings from "Scientific America". San Francisco: W. H. Freeman \& Co Ltd., 172 pp.

ZIEGLER, P. A. 1982. Geological tlas of Western and Central Europe. The Hague: Shell International Petroleum Maatschappij B.V., 130 pp. [AQ14]

ZIEGLER, P. A. 1988. Evolution of the Arctic-North Atlantic and the Western Tethys. American Association of Petroleum Geologists Memoir 43, 198 pp.

Ziegler, A. M., SCotese, C. R., McKerrow, W. S., Johnson, M. E. \& BAMBACH, R. K. 1979. Paleozoic paleogeography. Annual Review of Earth and Planetary Sciences 7, 473-502. 
Figure 1. (Colour online) Number of publications in English per year between 1950 and 2017 on (a) palaeogeography, (b) continental drift and (c) plate tectonics. Compiled from Google Scholar (accessed on 5 December 2017), with the search parameter that 'palaeogeography' or 'paleogeography', 'continental drift' and 'plate tectonics' or 'plate tectonic', respectively, are included in the title of the publication. Regardless of the shortcomings of this approach the changes in publication density reflect the kick-off of the plate tectonics paradigm, the decrease of influence of the theory of continental drift and the overall popularity of palaeogeography after the theory of plate tectonics became accepted by the Earth sciences community.

Figure 2. Snider (1859) [AQ12] compiled these two maps (several decades before Alfred Wegener's theory of continental drift), depicting his version of how the African and American continents may once have fit together before subsequently becoming separated: (a) assumed configuration of continents in late Carboniferous time and (b) present configuration. These maps were made famous by the publications of Carozzi $(1969,1970)$, who reintroduced them to the geological readership in the 1970s as an early theory of continental drift.

Figure 3. Schematic view of a section of the Earth's surface to its core indicating that the continents (Sal) float on the outer viscous crust (Sima), according to Alfred Wegener's model of continental drift (Wegener, 1912a, p. 279).

Figure 4. Alfred Wegener's palaeogeographic reconstructions of the world for three periods (late Carboniferous, Eocene and older Quaternary) according to the theory of continental drift (from Wegener, 1929, fig. 4). The upper map shows the supercontinent of Pangaea. Shaded, ocean; dotted, shallow sea; latitude and longitude arbitrary.

Figure 5. Reconstruction of Gondwana for the Palaeozoic Era according to du Toit (1937, fig. 7). The space between the various portions was then mostly land. Short lines indicate the pre-Cambrian or early Cambrian grain. Stippling marks out regions of late Cretaceous and Tertiary compression. Later, Smith \& Hallam (1970) presented a computer fit of the contour of the southern continents forming Gondwana-Land.

Figure 6. (Colour online) Pre-Permian ('Hercynian') palaeogeographic reconstructions for the assemblage of the circum-Atlantic continents. (a) Reconstruction based on a composite bathymetric map of the Atlantic Ocean, choosing the continental edge instead of the coastline as the relevant continental boundaries (Choubert, 1935, fig. 2). Choubert (1981) provides some information on how he worked out his 1935 reconstruction. (b) Reconstruction achieved by fitting of the continental margins at the 500 fathom line (approximately $900 \mathrm{~m}$ ) as a proxy for the edge of the continental shelf (Bullard et al. 1965, fig. 8). Red, overlaps; blue, gaps. The so-called 'Bullard fit' described the first use of numerical methods to 
generate a computerized fit of the continents. Reprinted from Bullard, E., Everett, J. E. \& Smith A. G. 1965, The fit of the continents around the Atlantic, Philosophical Transactions of the Royal Society of London, Series A, Mathematical and Physical Sciences 258, 41-51, by permission of the Royal Society.

Figure 7. Schematic model showing convection currents being responsible for continental drift (Ampferer, 1925, his fig. 6). Translation of the German words: Kontinentalscholle, continent; aufsteigende Strömung, ascending current; absteigende Strömung, descending current; Antrieb von innen, drive from the inside.

Figure 8. John Tuzo Wilson's sketch maps illustrating the present network of mobile belts, comprising the active primary mountains and island arcs in compression (solid lines), active transform faults in horizontal shear (light dashed lines) and active mid-ocean ridges in tension (bold dashed lines) (Wilson, 1965, fig. 1). Reprinted by permission from Macmillan Publishers Ltd: Nature. Wilson J. T., A new class of faults and their bearing on continental drift. Nature 207, 343-347 (1965), copyright 1965.

Figure 9. Robert de Lamanon's map of Montmartre (central part of the Paris Basin) at the time of the existence of the lake (de Lamanon, 1782). To the authors' knowledge, this is the earliest palaeogeographical map.

Figure 10. (Colour online) Melchior Neumayr's famous map showing the geography of the Jurassic Period (Neumayr, 1885, plate I) is the most detailed palaeogeographic map of the entire Earth published during the 19th century. Translation of the legend: Meer der borealen Zone, sea of the boreal zone; Meer der nördlichen u. südlich gemässigten Zone, sea of the northern and the southern temperate zone; Meer der aequatorialen Zone, sea of the equatorial zone. White indicates land areas and the coloured regions are the seas.

Figure 11. (Colour online) Jules Marcou's reconstruction of the palaeogeography of the Jurassic Period showing the distribution of oceans and continents and biogeographic provinces (Marcou, 1857-1860, foldout plate II). Blue shows the seas and white the lands. The explanations hardly need a translation except for pointillie (dotted) and suivant (following).

Figure 12. (Colour online) Palaeogeographic map for the Cretaceous Period reproduced from Arldt (1907).

Figure 13. Palaeogeographic map for the Silurian Period reproduced from Kossmat (1908). 
Figure 14. Palaeogeographic map of North America for the Silurian reproduced from Willis (1909).

Figure 15. Palaeogeographic map of North America for the Middle Silurian reproduced from Schuchert (1910). The legend to the left explains the facies presented on the map.

Figure 16. Alfred Wegener's reconstructions of the former supercontinent of Pangaea. (a) Palaeogeographic map of the Carboniferous, with the climatologically sensitive rock types indicating geographical environments (Köppen \& Wegener, 1924, fig. 3). E, traces of ancient glaciers/ice; K, coal; S, salt; G, gypsum; W, desert sandstone; dotted fields highlight arid areas. (b) Palaeogeographic map showing the distribution of flora during the Carboniferous and the Permian (Köppen \& Wegener, 1924, fig. 8). The diverse geological and climatological data from different continents fit like a jigsaw puzzle on this reconstruction. Panthalassa from the Greek $\pi \tilde{\alpha} v$ (pan) meaning 'all' and $\theta \alpha ́ \lambda \alpha \sigma \sigma \alpha$ (thálassa) meaning 'sea' was the giant ocean that surrounded Pangaea.

Figure 17. (Colour online) Boris Choubert's palaeogeographic fit of the circum-Atlantic continents at the end of the 'Hercynian epoch', with the superimposed geology of the Precambrian and Palaeozoic orogens ('terrains plissés') and non-folded areas ('terrains non plissés') (reproduced from Choubert, 1935, plate A).

Figure 18. Boris Choubert's palaeogeographic reconstructions for the Palaeozoic Era are probably the first which seriously considered continental drift (reproduced from Choubert, 1935, fig. 3). Geological times have been added according to Choubert's descriptions, but using modern stratigraphic terminology. Precambrian continental masses (cratons) are shown in dotted pattern. Active mountain belts are shown in black. Choubert's original descriptions are as follows. Pre-Hercynian orogenies: (I) late Cambrian and Early Ordovician; (II) Late Ordovician, Continent Laurentia (Taconic mountain belt). Middle and Late Ordovician, Continent Baltica: (III) late Gothlandian (Caledonian mountain belt). Post-Downton, Continent Laurentia. Before and Post-Downton, Continent Baltica: (IV) Late Devonian (Acadian mountain belt). Hercynian orogeny: (V) late Dinantian (Sudetic phase); (VI) late Westphalian [AQ13] (main Hercynian phase); (VII) Stephanian-Permian (Appalachian phase); (VIII) sketch referring to the main maps. Dotted pattern, outline of the Precambrian continental masses (position at the beginning). Regular bold lines, outline of the Precambrian continental masses (new position, at the end of each advance). Regular fine lines, outline of the Precambrian continental masses impossible to specify at present. Hatching, geoanticline formation, or rise of sialic Precambrian. Black, geoanticlines already formed. Light grey, previously formed chains (IV-VII). Dark grey, Precambrian continental masses. Fine dots, outline of geography (VIII). 
Figure 19. Selection of palaeogeographic reconstructions highlighting some major milestones from recent years. (a) Age-area distribution of ocean crust at the time of formation (based on the EARTHBYTE mantle frame; Müller et al. 2016) illustrated for the Middle Triassic at 230 Ma (after Torsvik \& Cocks 2017, fig. 11.1a, reprinted with permission from Cambridge University Press). CC, Cache Creek Oceanic Plate; FAR, Farallon Plate; IZA, Izanagi Plate; MO, Mongol-Okhotsk Ocean; PHX, Phoenix Plate. (b) Reconstruction for the early Eocene at 50 Ma showing absolute speed of plate motion (after Matthews et al. 2016, fig. 10, reprinted with permission from Elsevier). Colours and vector lengths indicate plate speed, and vector azimuths indicate absolute plate motion directions. Present-day coastlines (black) are also reconstructed. (c) Reconstruction for the Maastrichtian at c. 70 Ma with specifying palaeodrainage systems (after Markwick \& Valdes, 2004, fig. 10, reprinted with permission from Elsevier). (d) Smoothed global topography and bathymetry reconstruction for the middle-late Eocene at c. $38 \mathrm{Ma}$ (after Baatsen et al. 2016, fig. 6, reprinted under a Creative Commons Attribution 3.0 Unported License). 


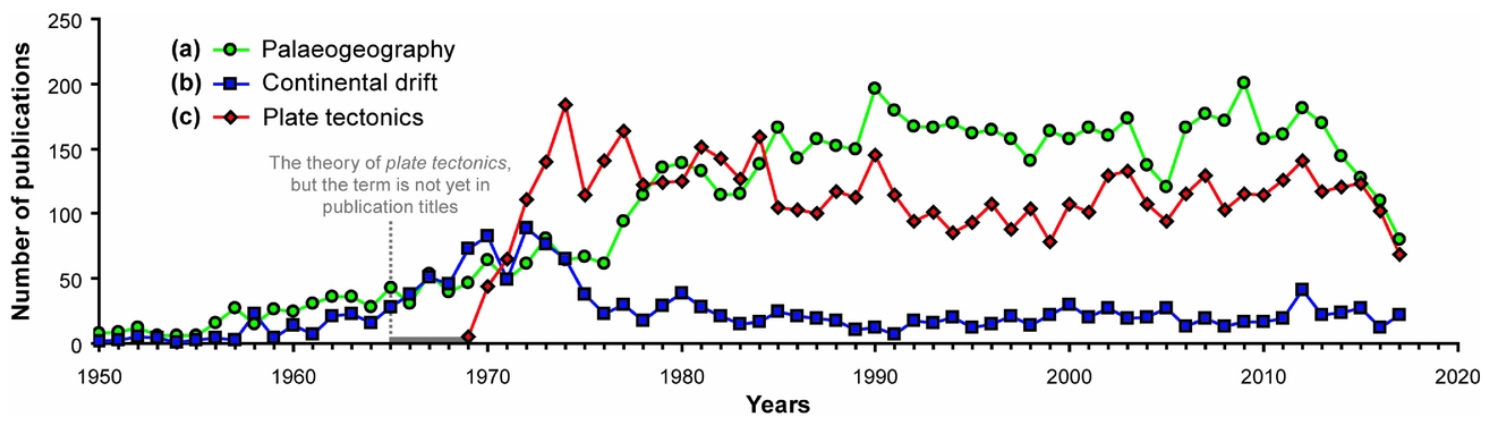

Fig. 1 

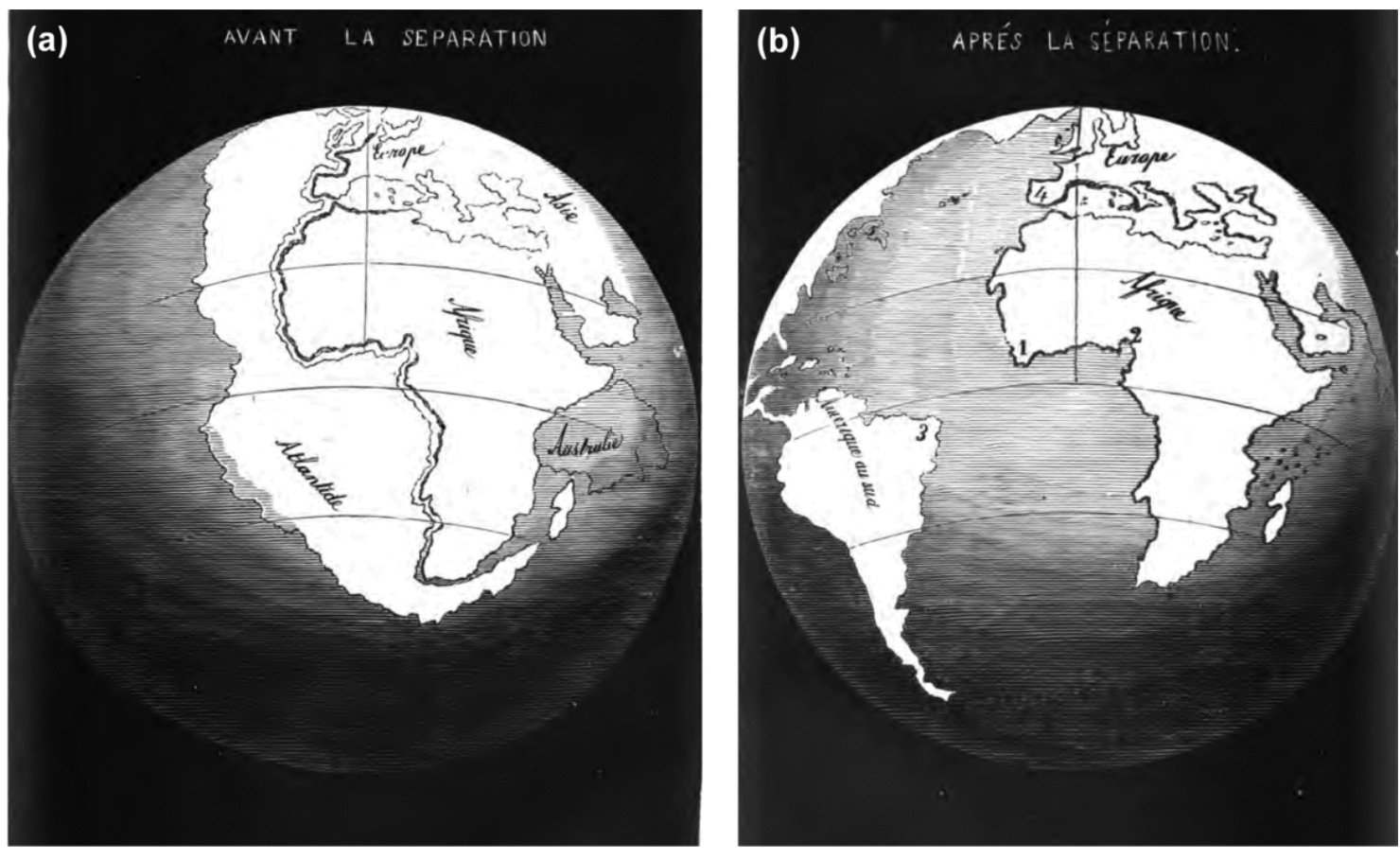

Fig. 2 


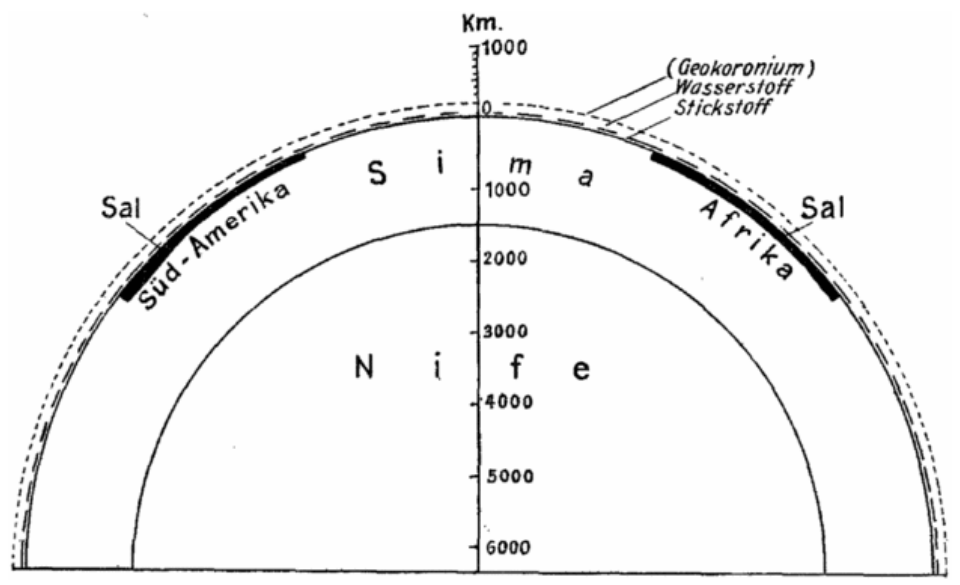

Fig. 3 

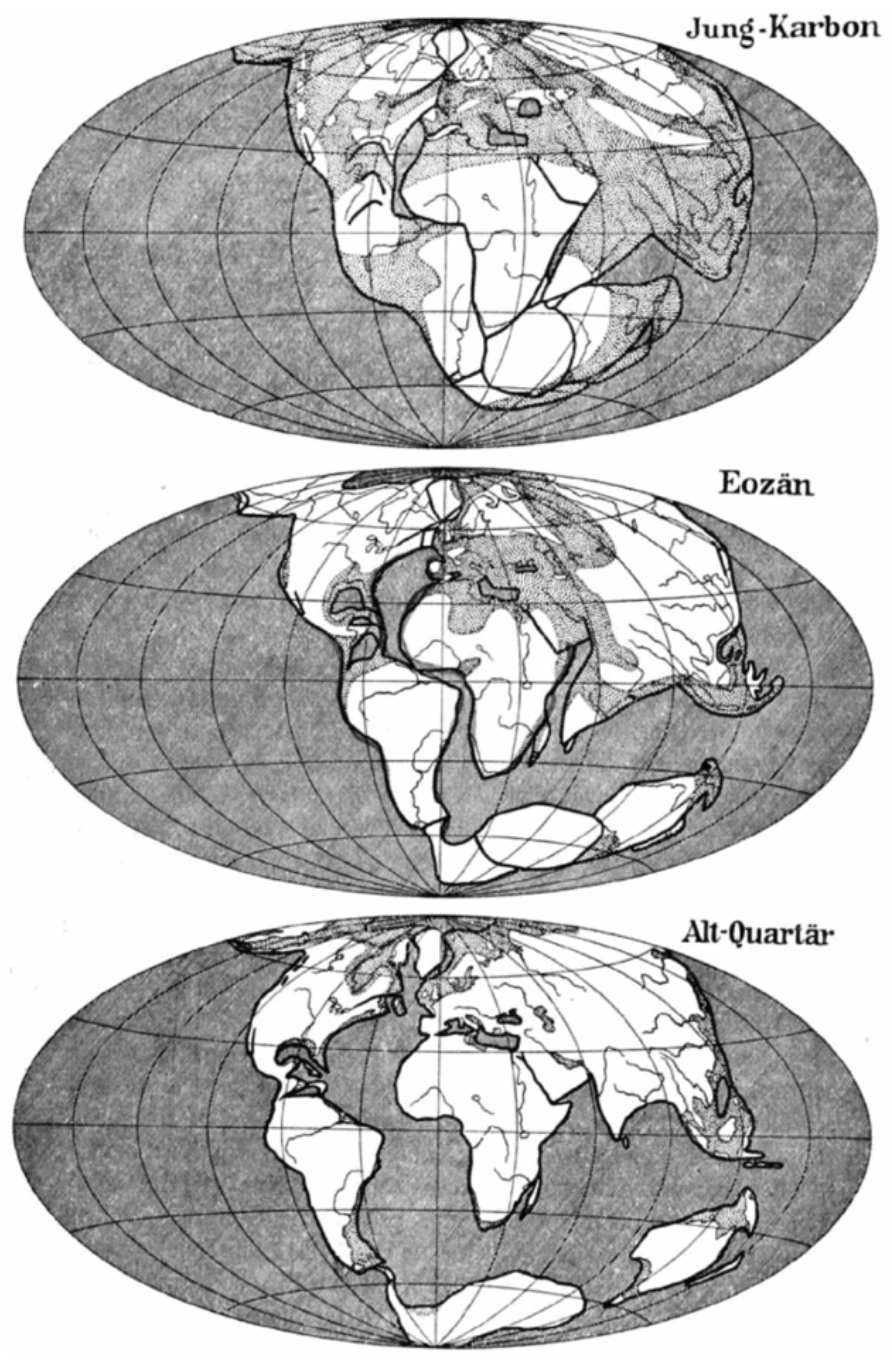

Fig. 4 


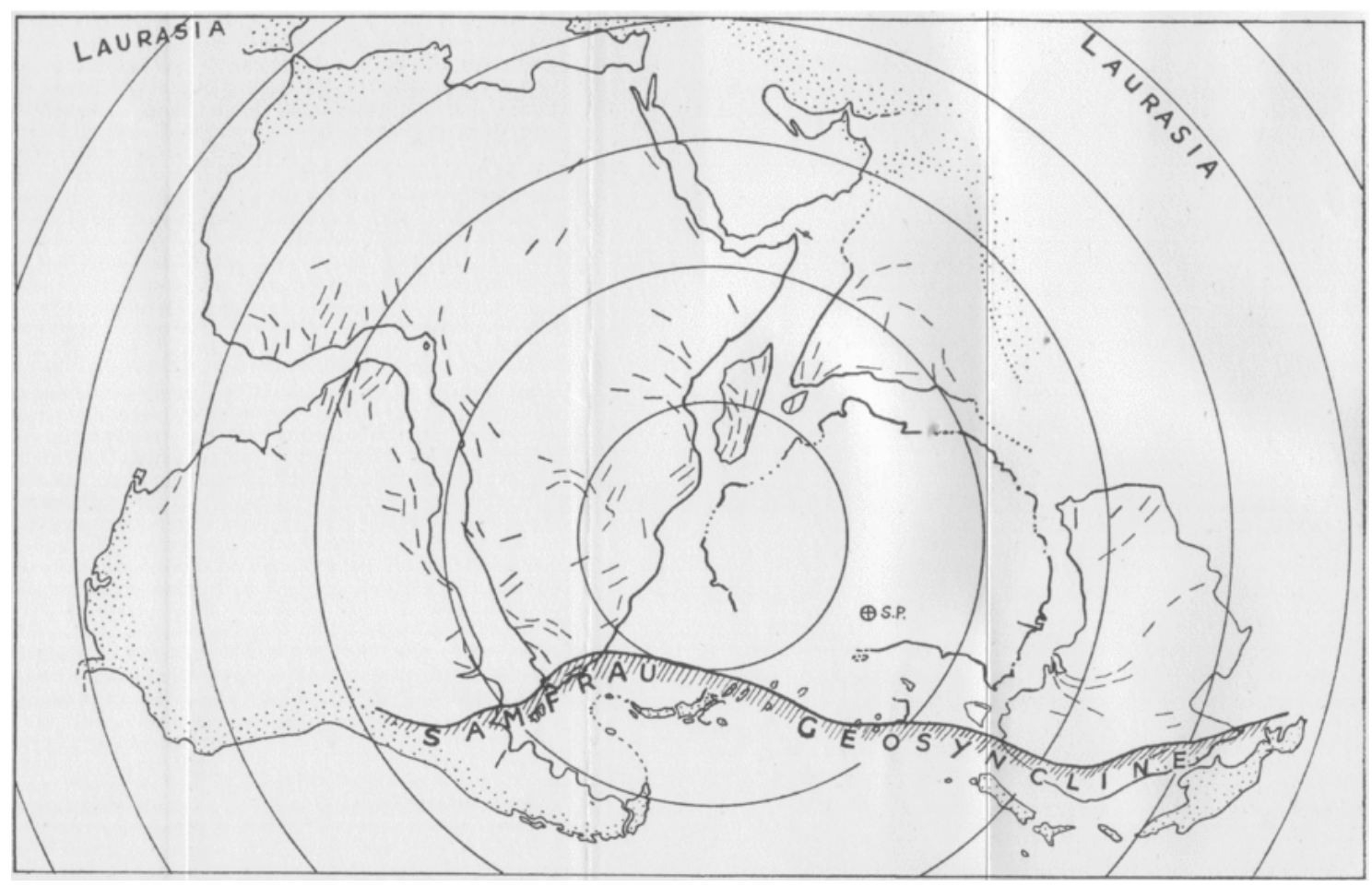

Fig. 5 
(a)

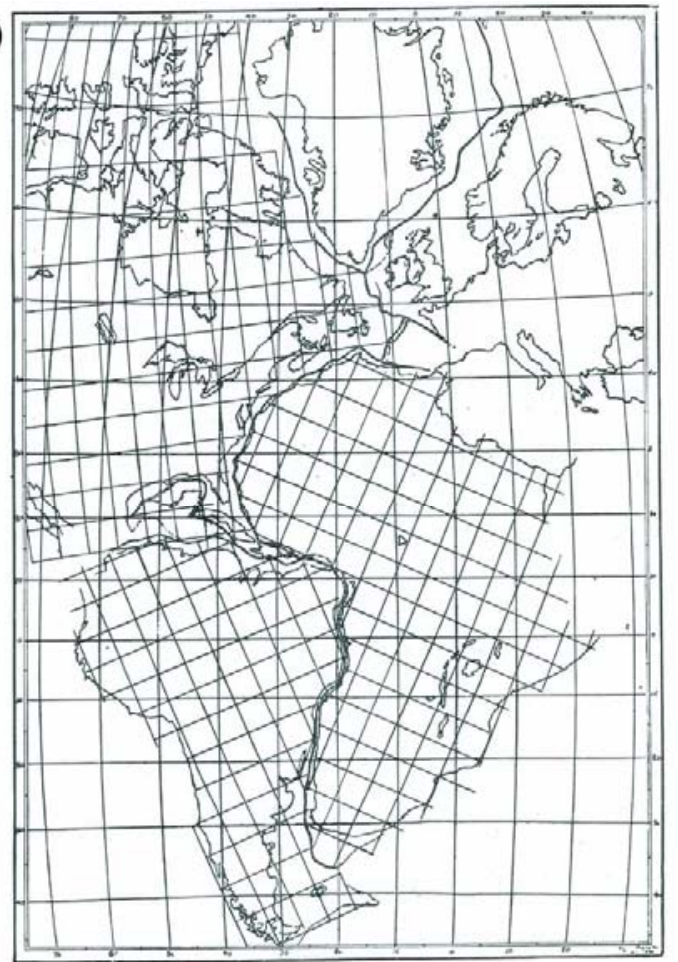

'Choubert fit', 1935

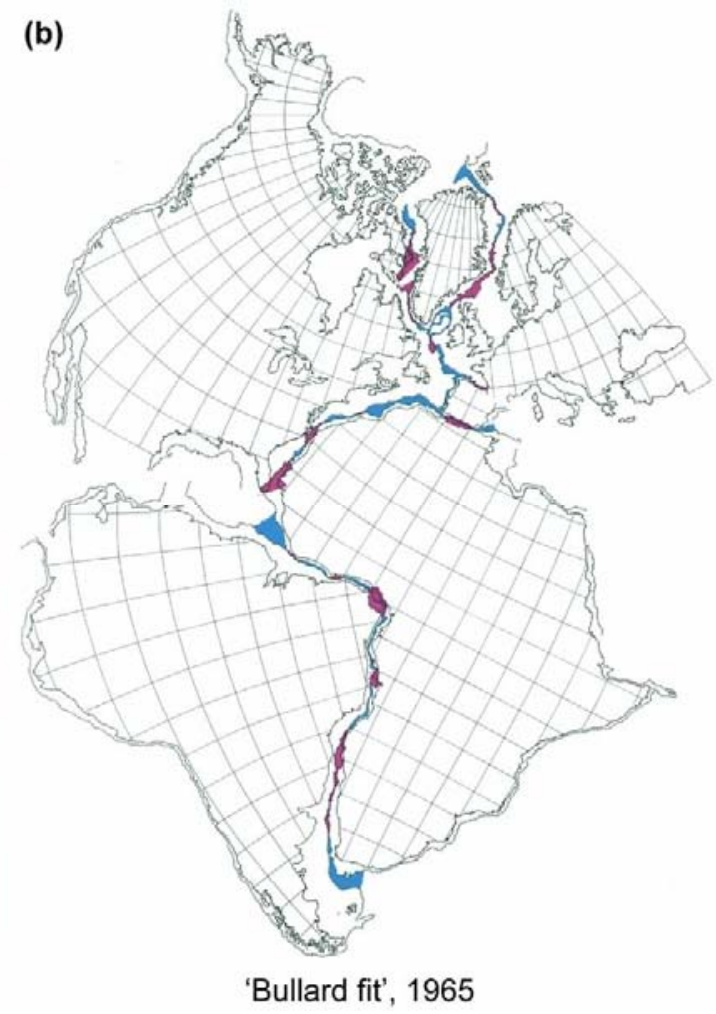

Fig. 6 


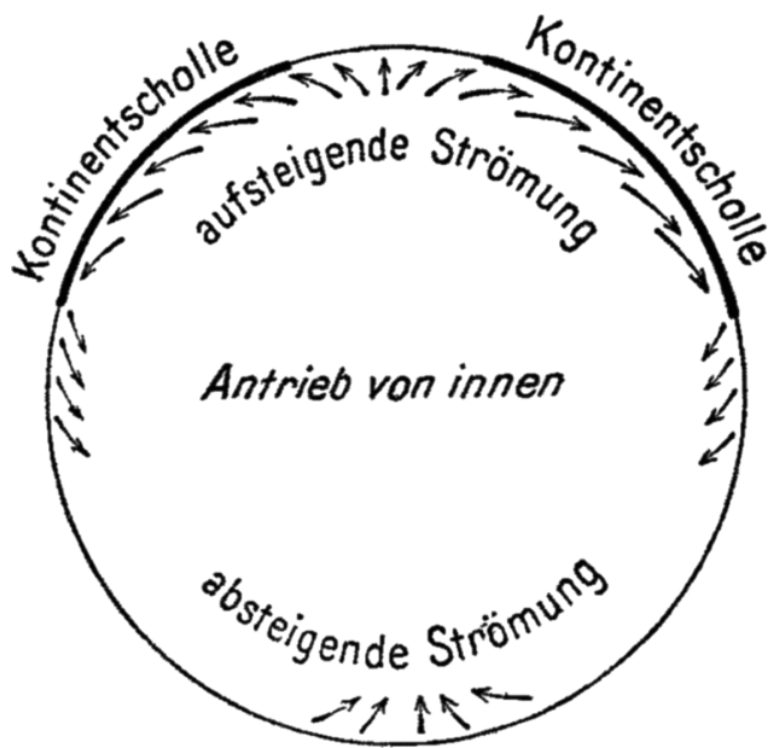

Fig. 7 


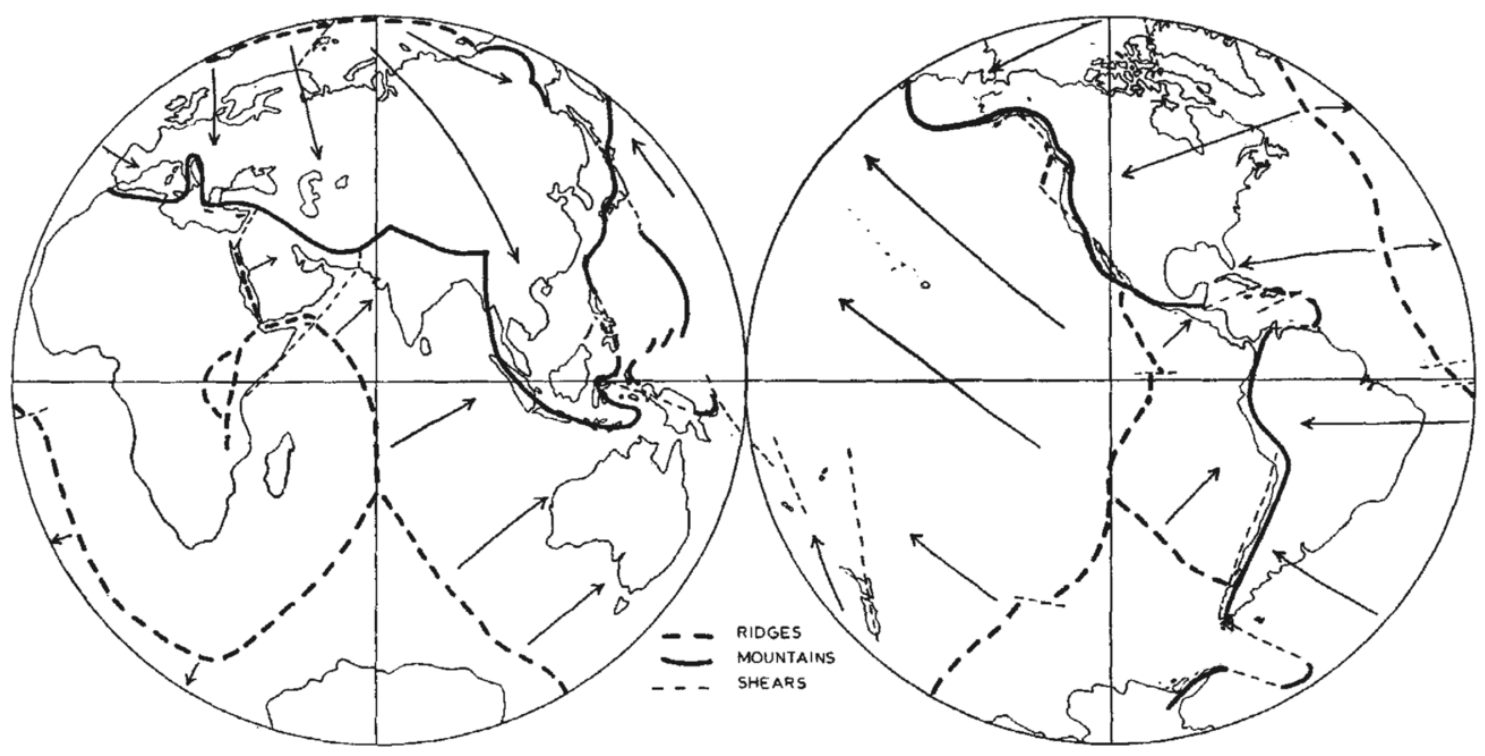

Fig. 8 


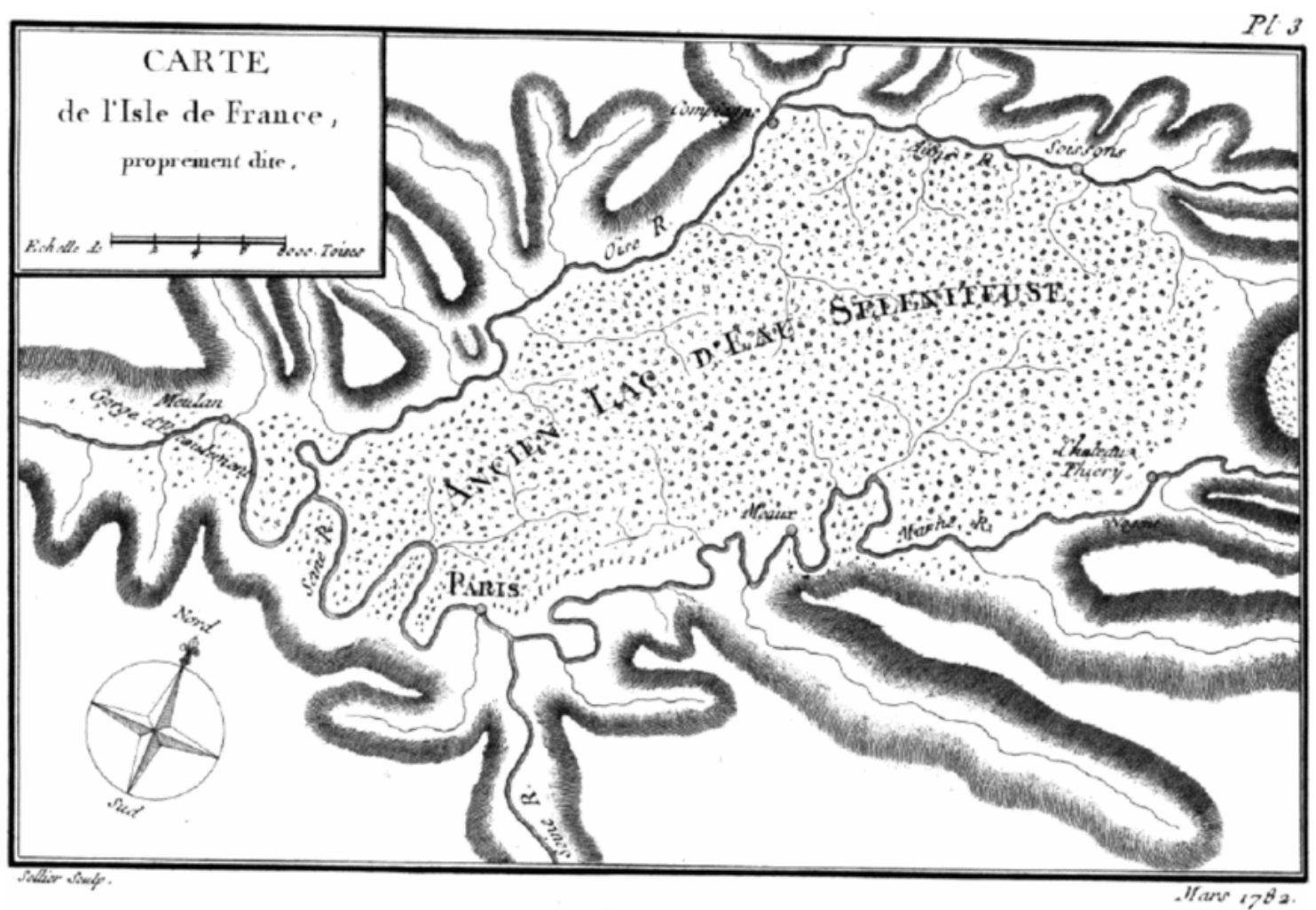

Fig. 9 


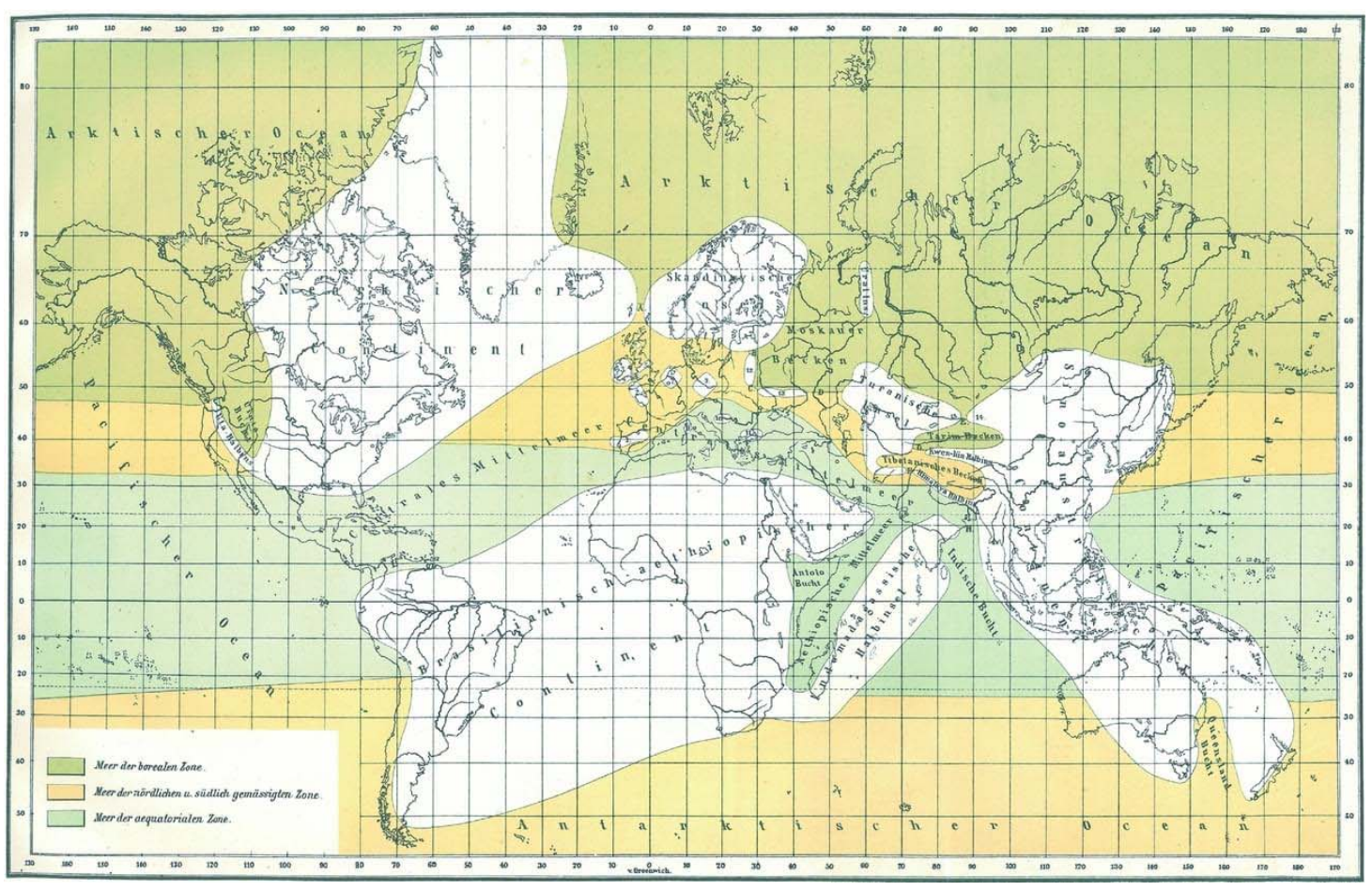

Fig. 10 


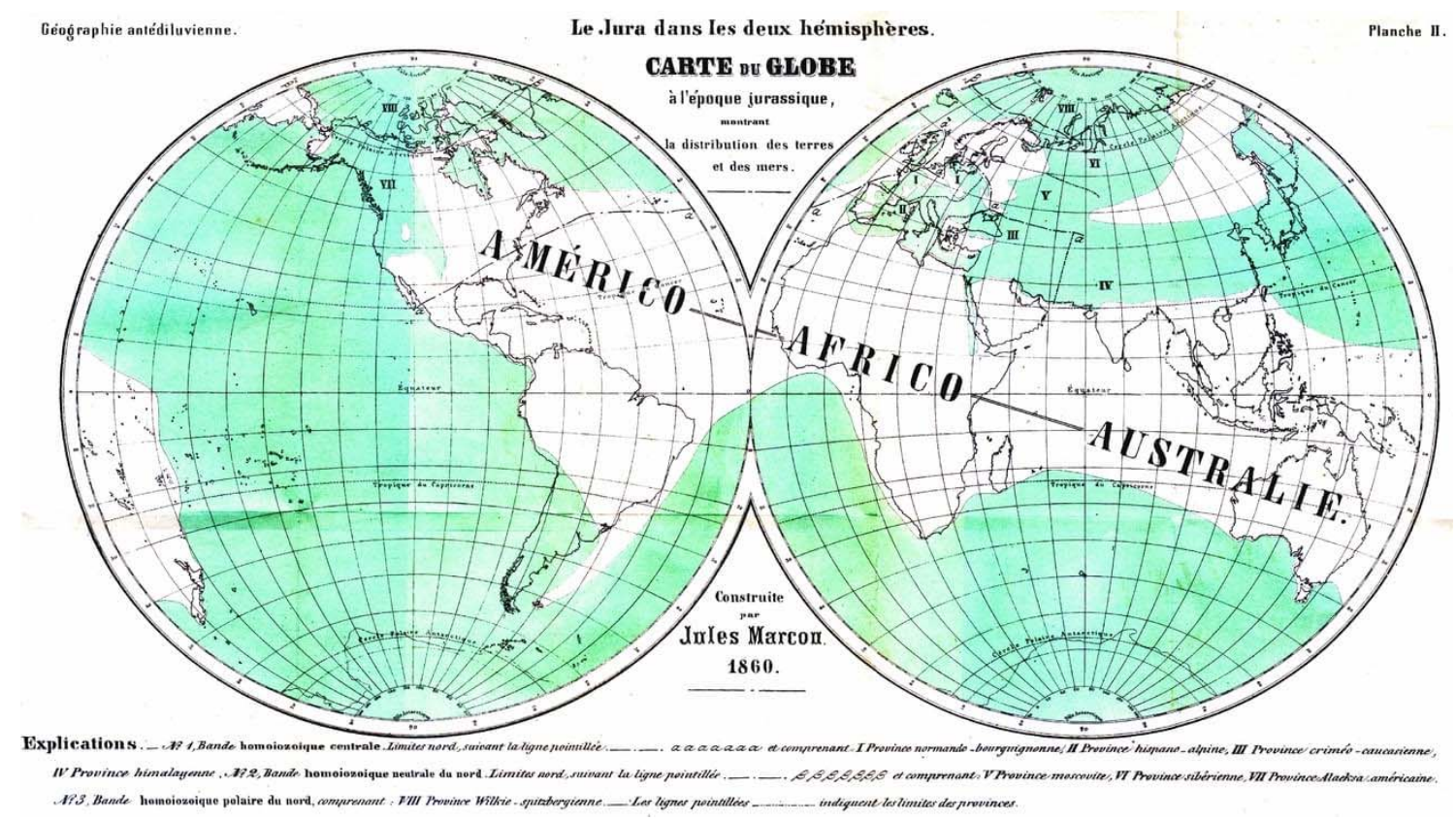

Fig. 11 


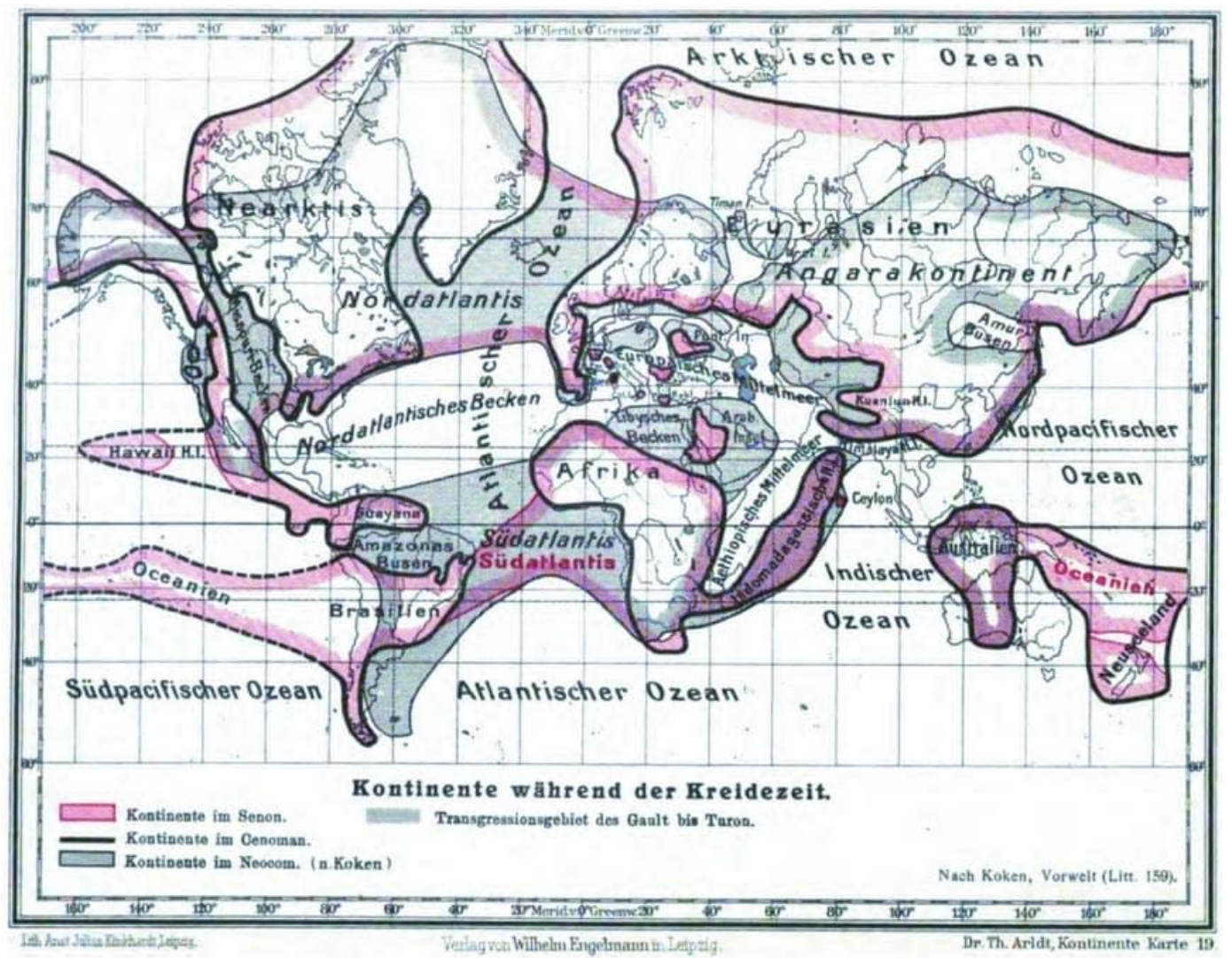

Fig. 12 


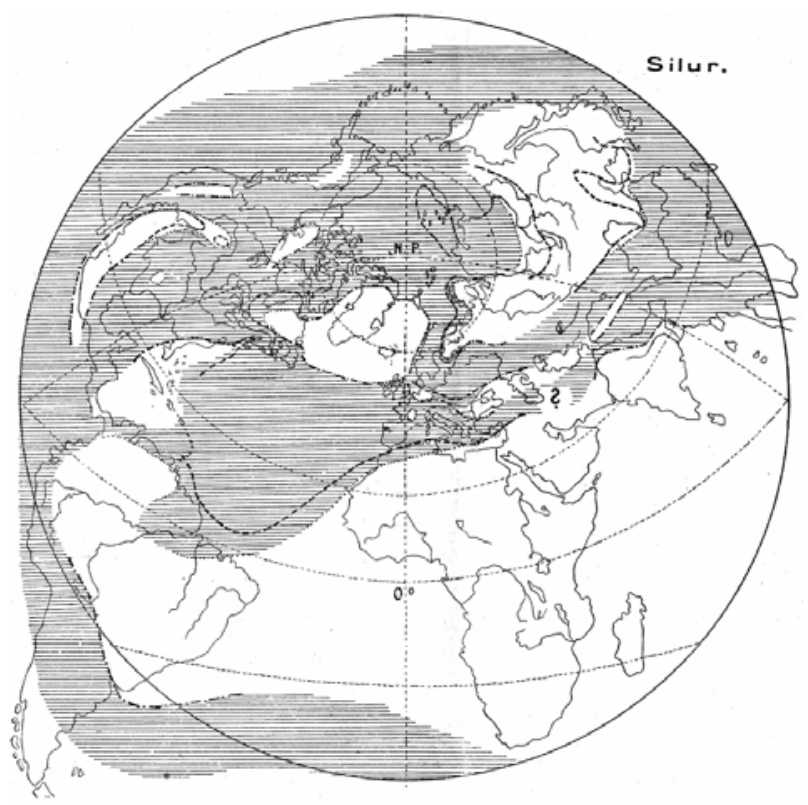

Fig. 13 


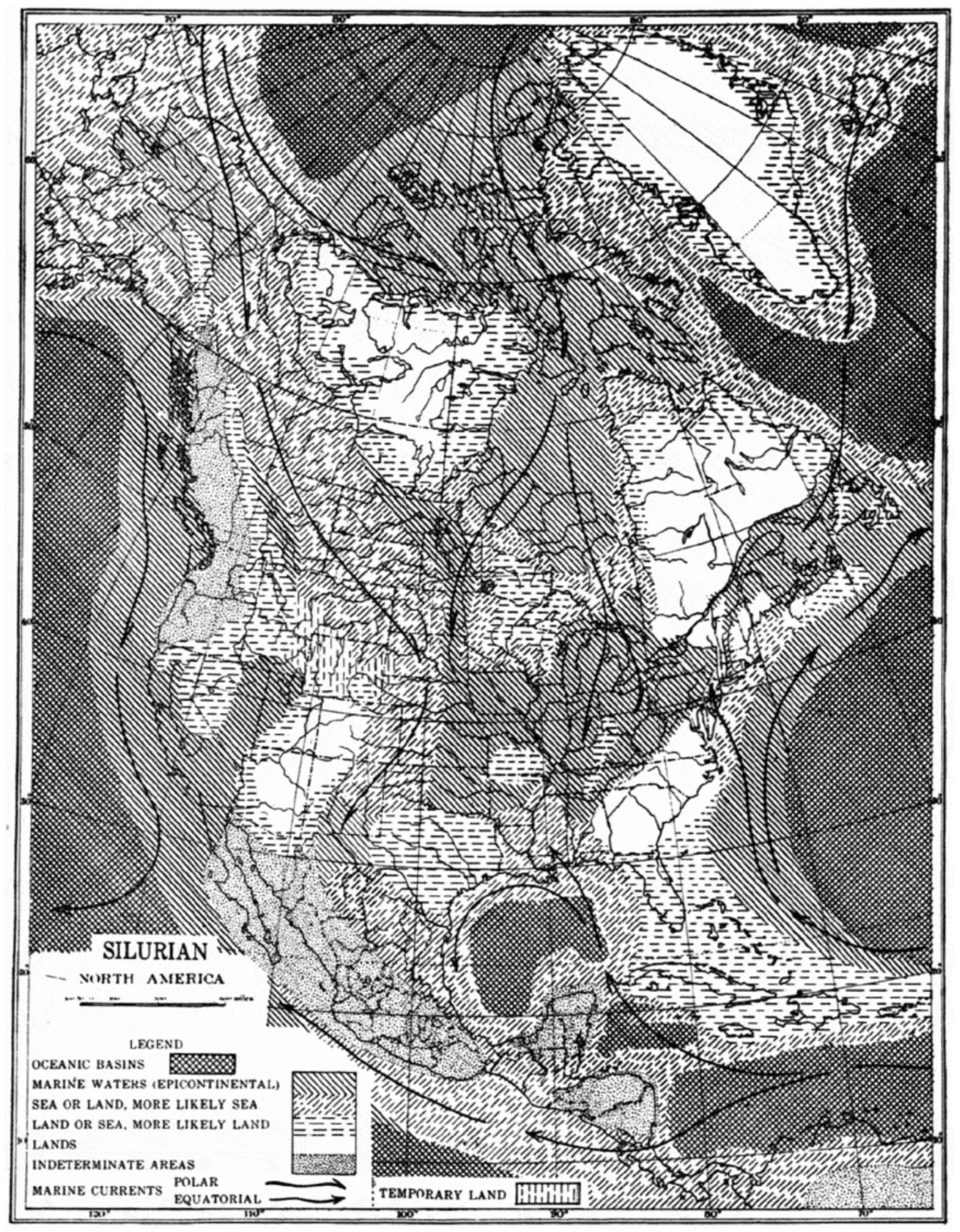

Fig. 14 


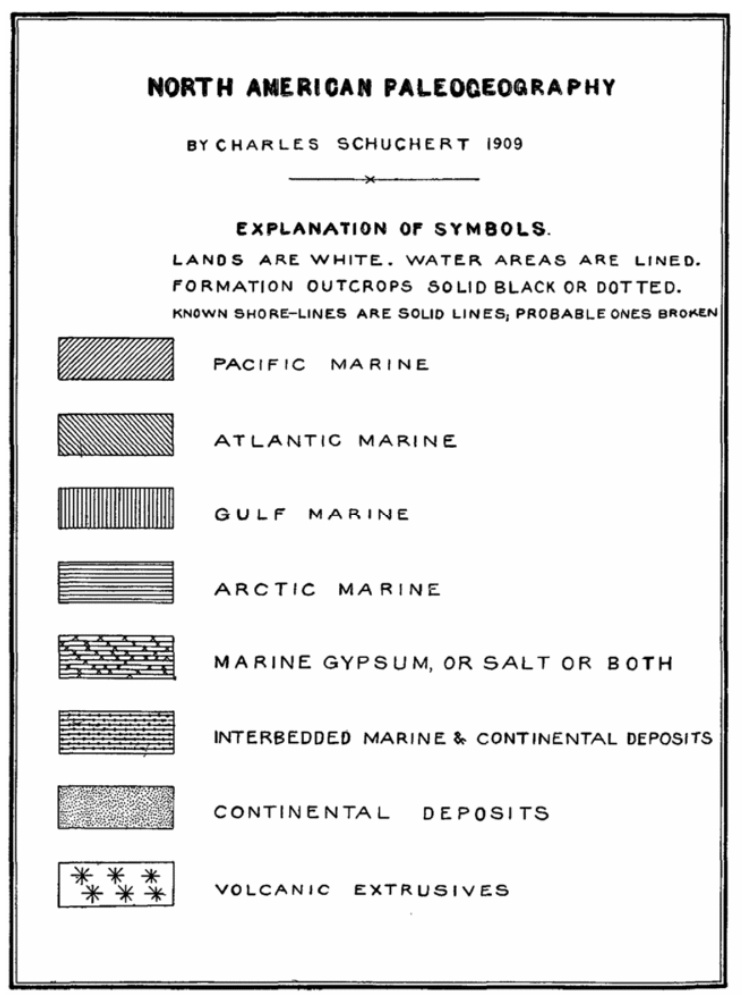

EXPLANATION OF SYMBOLS

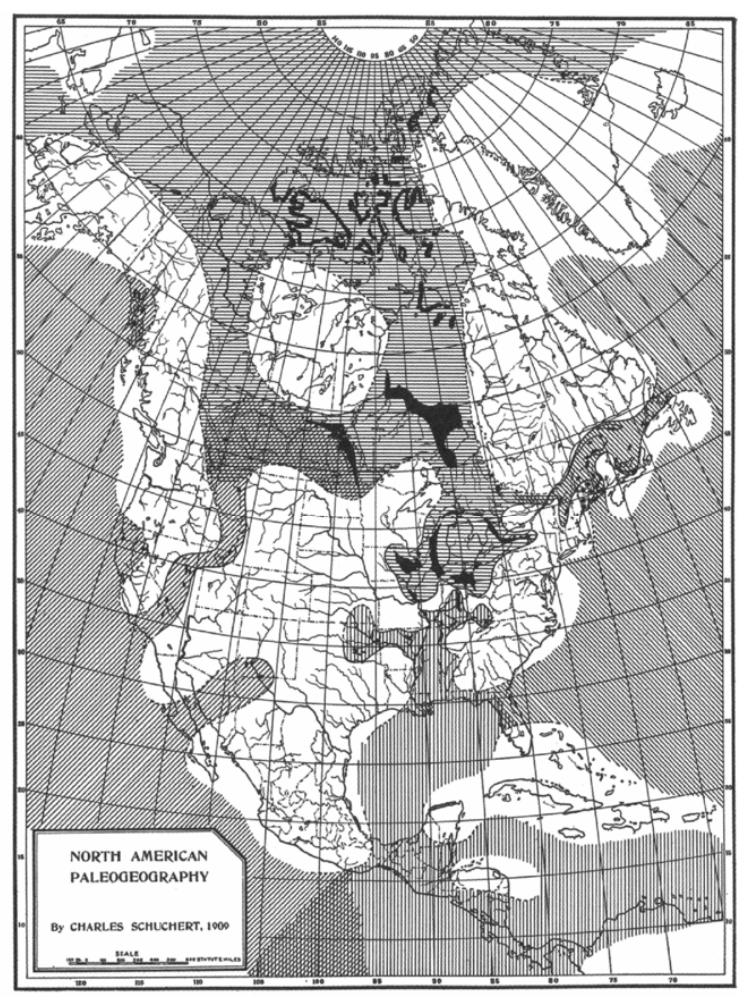

MIDDLE SILURIC (LOUISVILLE)

Fig. 15 


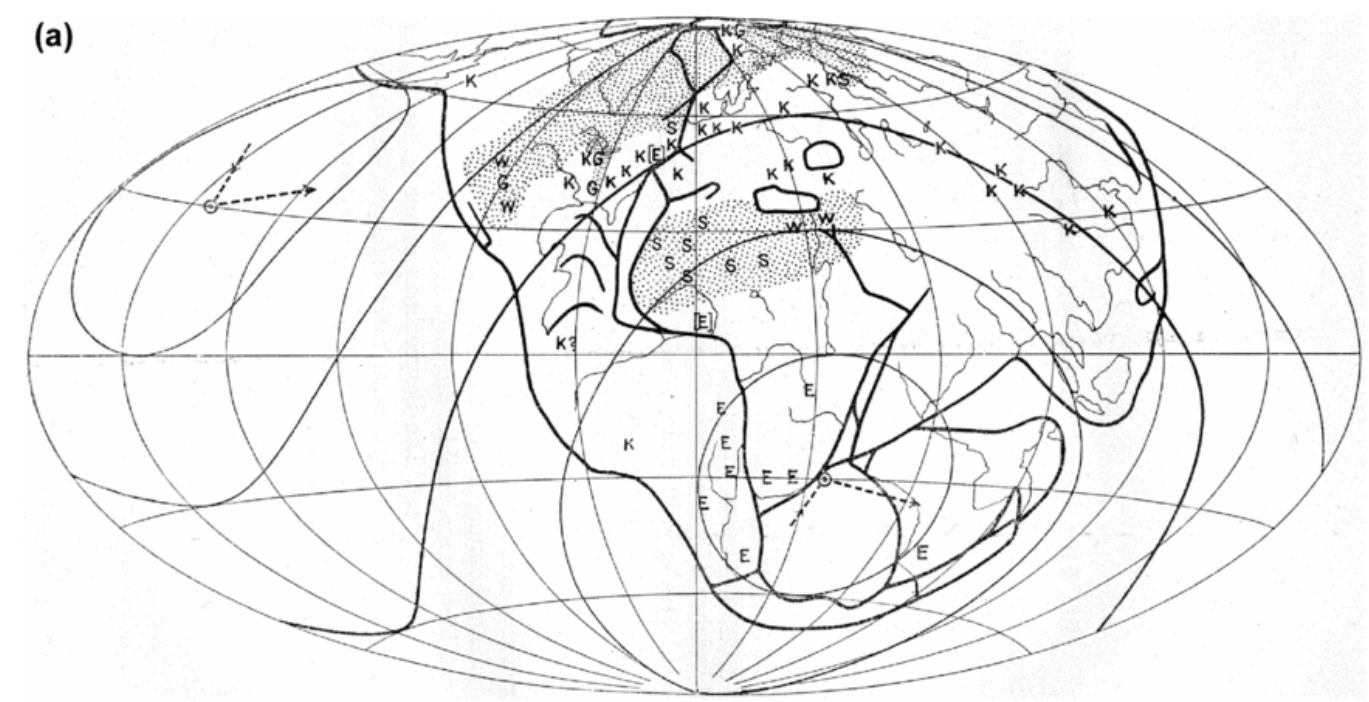

(b)

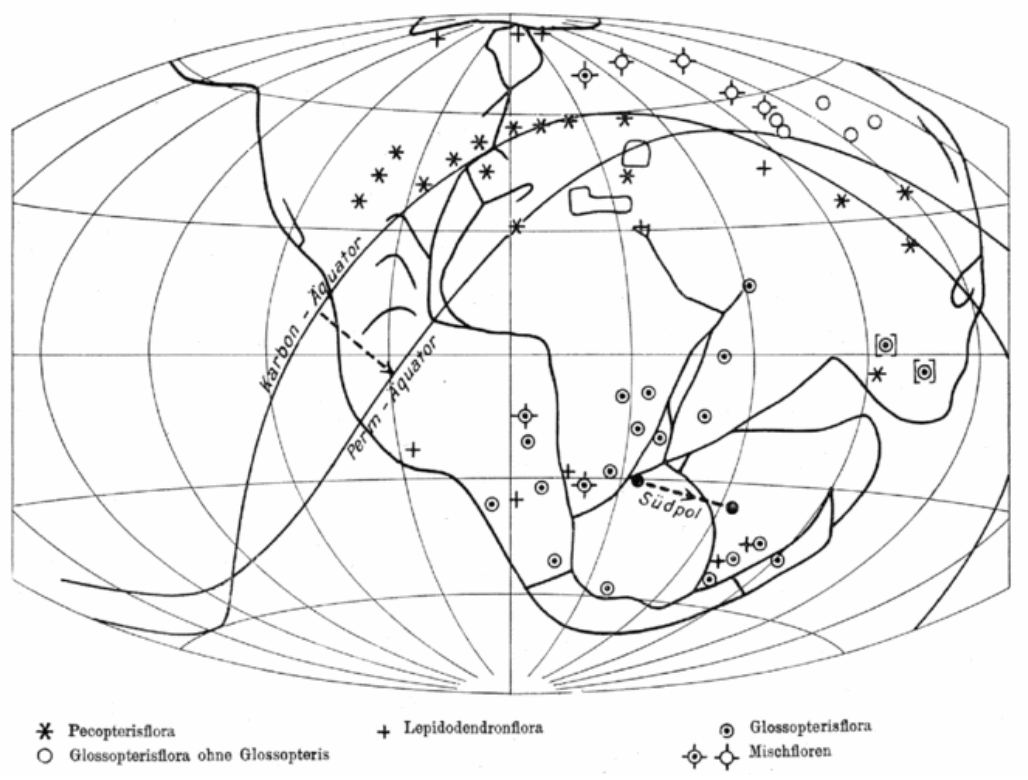

Fig. 16 


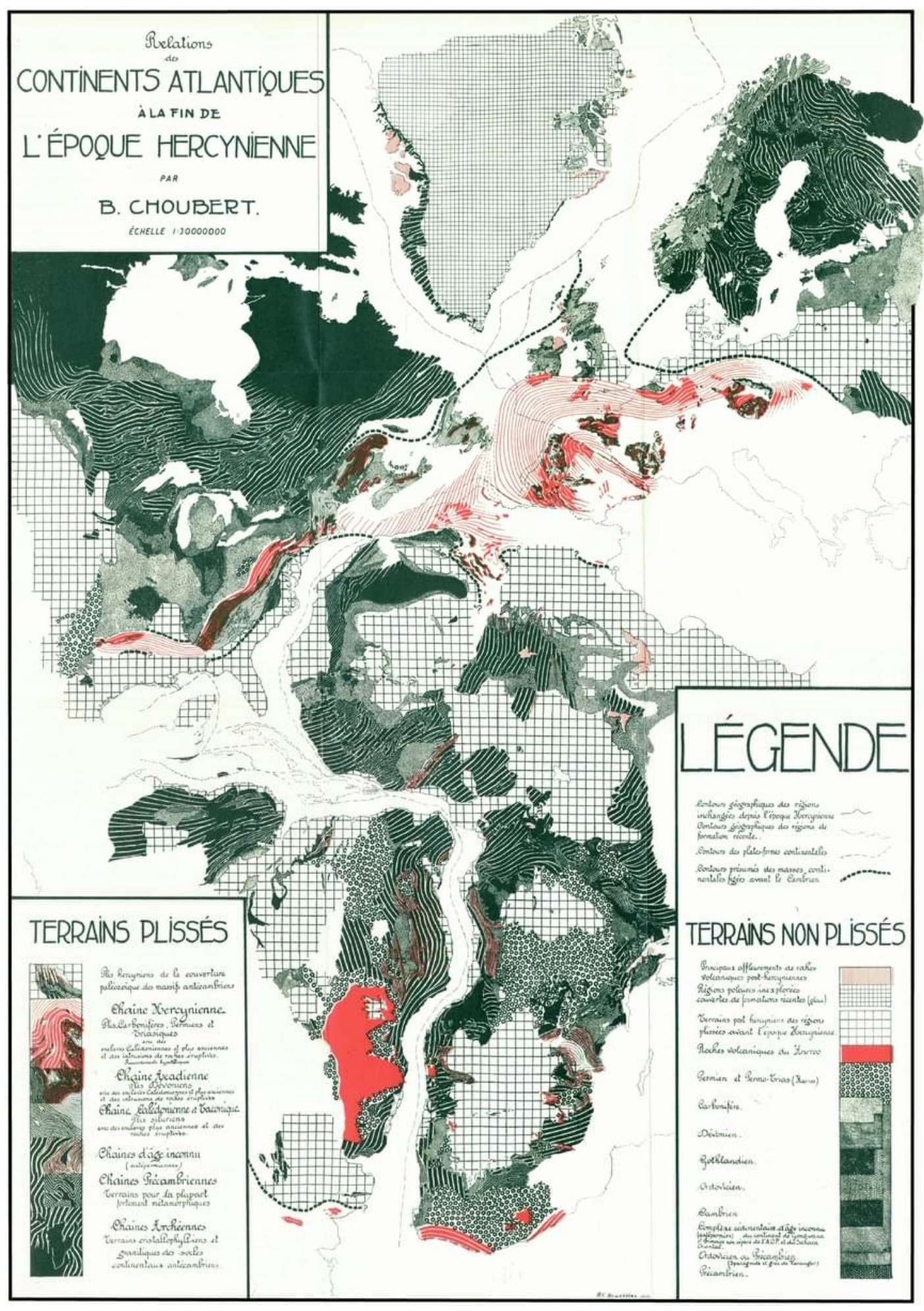

Fig. 17 

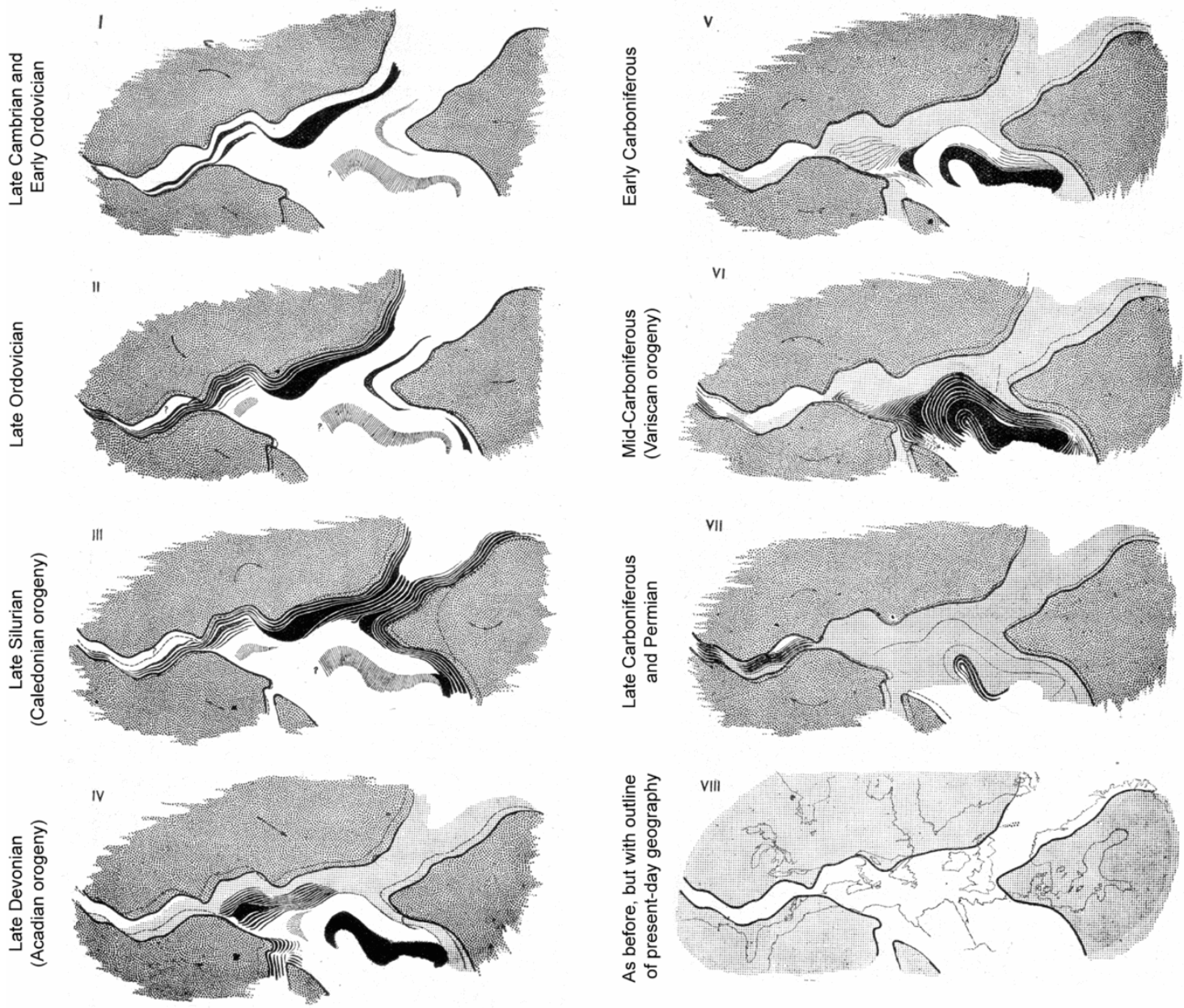

Fig. 18 
(a) Age of oceanic lithosphere back in time

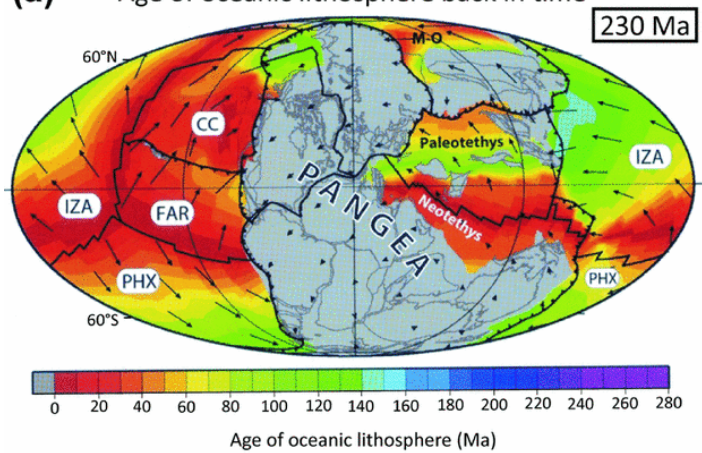

(c) Palaeotopography and drainage systems

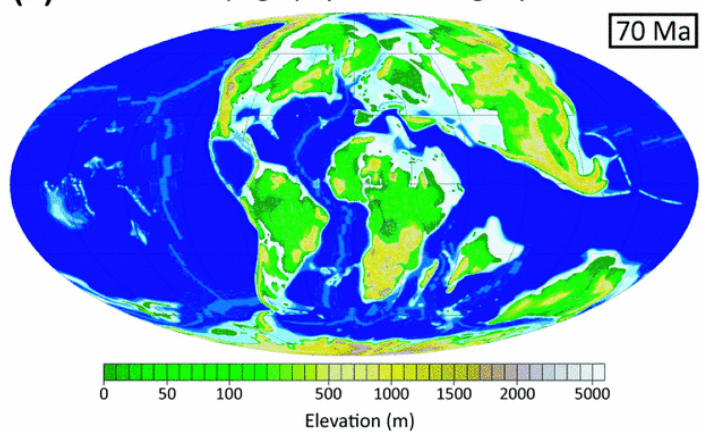

(b) Absolute plate motion speed and direction

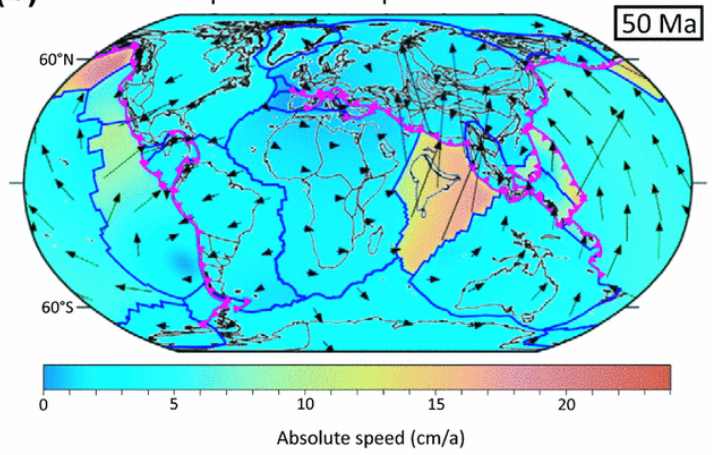

(d)

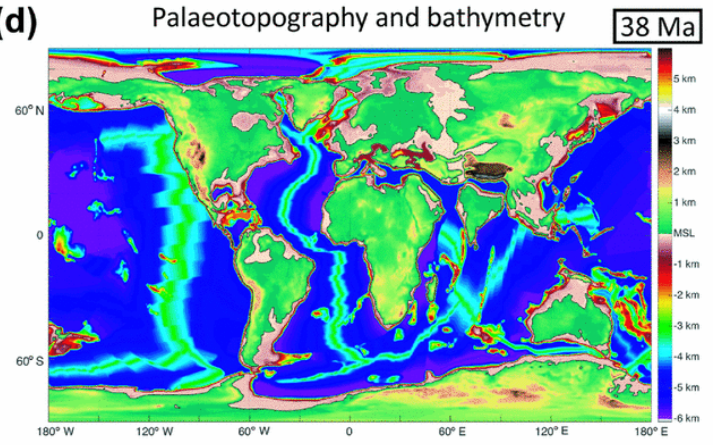

Fig. 19 